Supporting Information

\title{
Highly Selective Fluorescent Probe Design for Visualizing Hepatic Hydrogen Sulfide in the Pathological Progression of Nonalcoholic Fatty Liver
}

Wei Li, YangShen, XiangyangGong, Xiao-BingZhang, Lin Yuan*

State Key Laboratory of Chemo/Biosensing and Chemometrics, College of Chemistry and Chemical Engineering, Hunan University, Changsha 410082, China

E-mail: lyuan@hnu.edu.cn (L. Y) 


\section{Table of Contents}

1.Experimental procedures S3-S4

2.The synthesis and characterization of compounds S5-S7

3. Spectra and biological studies S8-S19

4. NMR and MS spectra of synthesis compounds S20-S27

5. References S28 


\section{Experimental Procedures}

Materials and instruments. All chemical reagents for synthesis were obtained from commercial suppliers and were used in whole experiment without further purification, and solvents used were purified by standard methods before using. The water used in the whole experiment was twice-distilled water. ${ }^{1} \mathrm{H}$ NMR and ${ }^{13} \mathrm{C}$ NMR spectra were recorded on a Bruker-400 spectrometer with an internal standard (TMS). Mass spectra were performed using an LCQ Advantage ion trap mass spectrometer from Thermo Finnigan. High-resolution electron spray mass spectra (HRMS) were obtained from ESI/Q-TOF Micro TM HRMS (Zhengzhou University Analysis and Testing Center). Absorption and fluorescence spectroscopic studies were performed in a UV-1800 ultraviolet and visible spectrophotometer (Shimadzu Corporation, Japan) and a Hitachi F-4600 fluorescence spectrophotometer. A PHS-3C pH meter (INESA instruments) was used to measuring pH. Cell imaging was performed on Nikon A1 plus confocal microscope (Nikon, Japan). In vivo imaging was carried out on an IVIS Lumina XR (IS1241N6071) imaging system. TLC analysis and column chromatography were carried out by using silica gel plates and silica gel (mesh 200-300) columns (Yantai Jiangyou Silica Gel Development Company Limited). The zeta potential of nanoparticles was measured by dynamic light scattering (DLS) (Malvern Zetasizer Nano ZS90) at room temperature. Transmission electron microscope images (TEM) were recorded on a field-emission high-resolution $2100 \mathrm{~F}$ transmission electron microscope (JEOL, Japan).

Preparation of mesoporous silica (MSN). According to the method in the reference ${ }^{1}, 2.1 \mathrm{~g}$ of cetyltrimethylammonium bromide (CTAB) and $80 \mathrm{mg}$ of triethanolamine (TEA) was dissolved in $20 \mathrm{~mL}$ of water and heated at $80{ }^{\circ} \mathrm{C}$ for reaction $1 \mathrm{~h}$. At this time, the solution was translucent and milky white. Next, $1.5 \mathrm{~mL}$ of tetraethyl orthosilicate (TEOS) and $20 \mu \mathrm{L}$ of (3-aminopropyl) triethoxysilane (APTES) were slowly introduced into solutions for reaction $1 \mathrm{~h}$. After cooling, we used an ultra-high-speed centrifuge at 10,000 rpm for 20 minutes to obtain a milky white solid precipitate. The crude precipitates were washed with ethanol containing $10 \%$ concentrated hydrochloric acid for two times, and then washed with $1 \% \mathrm{NaCl}$ methanol solution for $12 \mathrm{~h}$ to remove the surfactant CTAB. Furthermore, the crude product was washed with water and re-dispersed in water to yield the amino-functionalized mesoporous silicon nanomaterials (MSN-NH2), confirming that its concentration was $14 \mathrm{mg} / \mathrm{mL}$ through freeze-drying.

Spectra Studies. For photophysical properties, the compounds 1-CSN, 2-SO $3 \mathbf{N}, 3-\mathrm{CHO}, 4-\mathrm{Thia}_{1}$ 5-BN $\mathrm{BN}_{3}$ and 6NBD were dissolved in DMSO to make the final stock solutions $(500 \mu \mathrm{M})$. Sources for different RSS/ROS/RNS are described as following. $\mathrm{Na}_{2} \mathrm{SO}_{4}, \mathrm{Na}_{2} \mathrm{SO}_{3}, \mathrm{Na}_{2} \mathrm{~S}_{2} \mathrm{O}_{3}, \mathrm{NaHSO}_{3}, \mathrm{NaSCN}, \mathrm{NaNO}_{2}$, and Se-Cys were dissolved in water. Specifically, $\mathrm{H}_{2} \mathrm{~S}$ and $\mathrm{H}_{2} \mathrm{~S}_{\mathrm{n}}$ were generated from that $\mathrm{Na}_{2} \mathrm{~S}$ and $\mathrm{Na}_{2} \mathrm{~S}_{2}$ were dissolved in water, respectively. Superoxide $\left(\mathrm{O}_{2} \bullet^{-}\right)$was generated from $\mathrm{KO}_{2}$ was dissolved in DMSO. $\mathrm{H}_{2} \mathrm{O}_{2}$ (SigmaAldrich) and $\mathrm{NaOCl}$ (commercial bleach) were added into the testing solution directly for required concentration. BSA and HAS were dissolved in PBS.

Cell culture and Cell cytotoxicity study. HL-7702 cells were cultured at $37{ }^{\circ} \mathrm{C}$ and $5 \% \mathrm{CO}_{2}$, using high glucose Dulbecco's Modified Eagle Medium (Hyclone) mixed with 10\% fetal bovine serum (Gemini) and 1\% antibiotics (100 U/mL penicillin and $100 \mu \mathrm{g} / \mathrm{mL}$ streptomycin, Hyclone). Cells were cultured in 96-well flat- 
bottomed plates for 24 h, and incubated nanoprobe MSN@CSN@PEG. Subsequent operations were based on standard MTT assay. Finally, the absorbance was measured at $490 \mathrm{~nm}$ by a multidetection microplate reader. The following formula was used to calculate the viability of cell growth: Cell viability $(\%)=($ mean of A value of treatment group - mean of A value of control) $\times 100$.

Fluorescence microscopic imaging. HL-7702 cells were plated with $1.0 \mathrm{ml}$ of DMEM (10\% FBS and $1 \%$ antibiotics) in a $35-\mathrm{mm}$ glass bottom dish and kept for $24 \mathrm{~h}$ at $37{ }^{\circ} \mathrm{C}$. Seeded density of cells were $60 \%$. And cells were incubated nanoprobe MSN@CSN@PEG $(100 \mu \mathrm{g} / \mathrm{mL}, 2 \mathrm{~h})$ then washed prior to imaging. The confocal imaging was performed using Nikon A1 plus confocal microscope with a $40 \times$ water objective. All live images were acquired with an environment chamber at $37{ }^{\circ} \mathrm{C}$. The fluorescence images of MSN@CSN@PEG were captured from the red channel of 663-738 nm with an excitation at $640 \mathrm{~nm}$. Images were acquired at 16-bit depth with Nikon Elements Software and processed in Image J2 software by calculating its average values. Three replicates were performed for each imaging experiment.

Related biological analysis. Blood analysis was performed by drawing blood from the eye frame. After the mice were sacrificed, fresh liver tissues were taken out for weighing analysis and divided into three parts. One part was fixed with $4 \%$ paraformaldehyde for HE staining analysis. The second and third parts were placed in centrifuge tubes and stored at $-80^{\circ} \mathrm{C}$ for Oil Red O (ORO) staining and western blot (WB) analysis. The WB experiment protocol was as follows: total protein was isolated according to standard procedures and quantified using nanodrop. The proteins were separated by $10 \%$ sodium dodecyl sulfate polyacrylamide gel electrophoresis (SDS-PAGE) and then transferred onto nitrocellulose membrane using standard protocol. To block nonspecific antibody binding, the membrane was treated with 5\% nonfat milk (dissolved in TBST) for $1.5 \mathrm{~h}$. Next, the membrane was incubated with antibodies for Mercaptopyruvate Sulfurtransferase (MPST, 1:100, Santa cat. no. sc-374326) or Gamma Cystathionase (CSE, 1:1000, Proteintech cat. no.12217-1-AP) or cystathionine- $\beta$-synthase (CBS, Proteintech cat. no.14787-1-AP) or $\beta$-actin (1:5000, Proteintech cat. no. 60008-1-Ig). The membranes were washed and incubated with HRP-conjugated goat anti-rabbit IgG (1:5000, Proteintech), then washed, and finally visualized using a chemiluminescence (ECL) system. 


\section{The synthesis and characterization of six compounds}
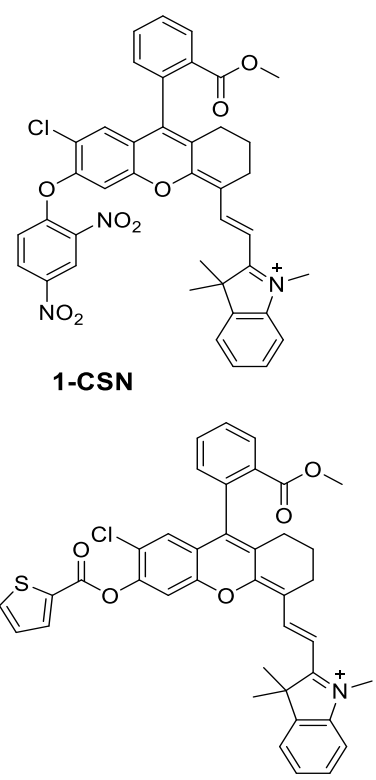

4-Thia
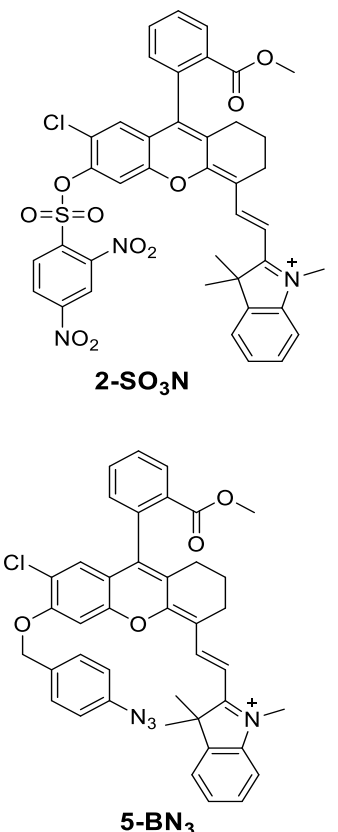
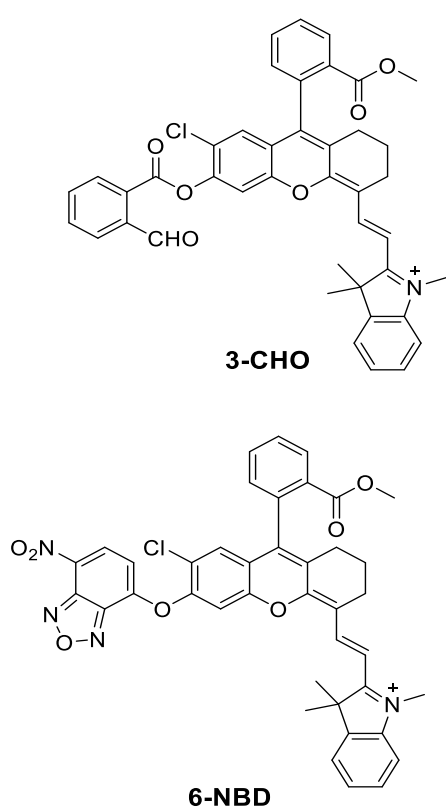

6-NBD

Scheme S1. The structure of compounds 1-CSN, 2-SO 3 N, 3-CHO, 4-Thia, 5-BN3 and 6-NBD.

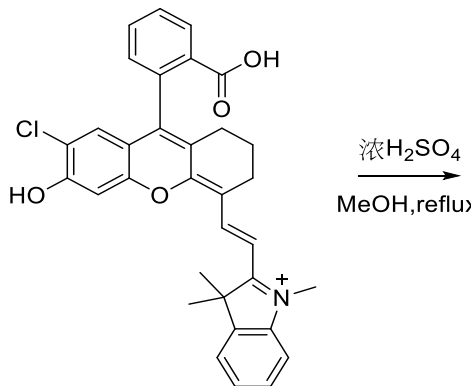

CSOH-CI-COOH

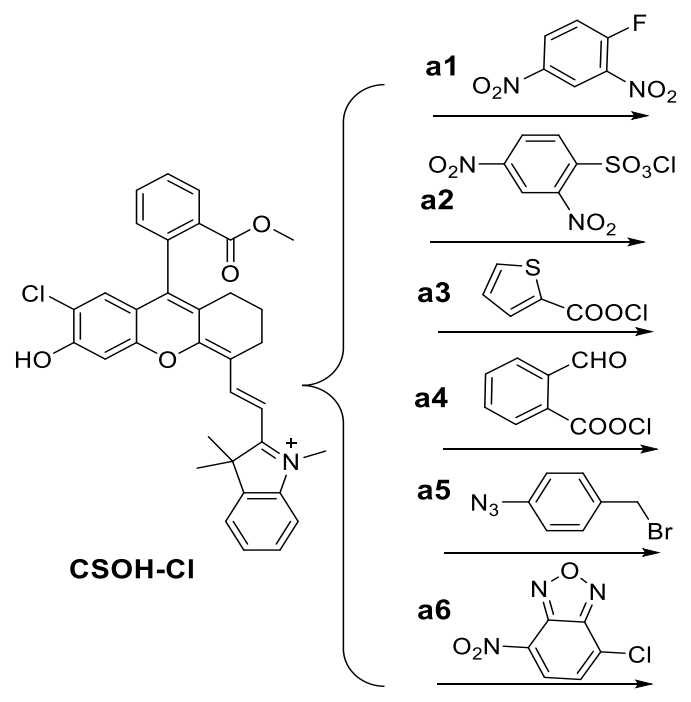<smiles>COC(=O)c1ccccc1C1=C2CCCC(/C=C/C3=[N+](C)c4ccccc4C3(C)C)=C2Oc2cc(O)c(Cl)cc21</smiles>

CSOH-CI
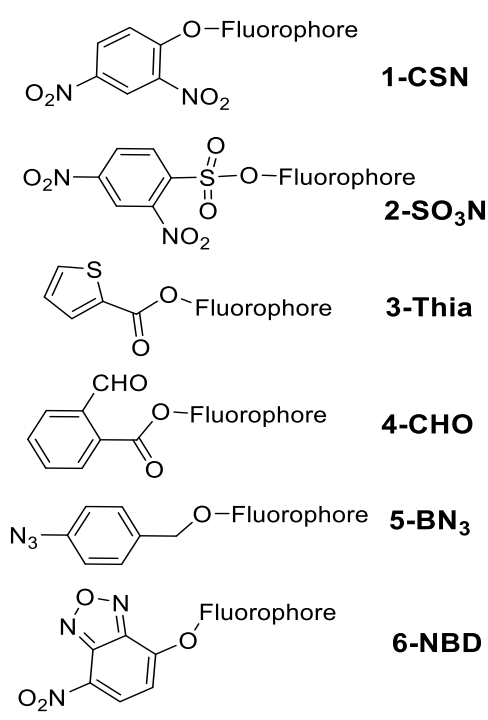

Scheme S2. Synthetic routes of compounds CSOH-Cl, 1-CSN, 2-SO 3 N, 3-CHO, 4-Thia, 5-BN 3 and 6-NBD. 
The compound CSOH-Cl-COOH was synthesized according to literature methods. ${ }^{2} \mathbf{C S O H}-\mathbf{C l}-\mathbf{C O O H}(800.3 \mathrm{mg}$, $1.48 \mathrm{mmol}$ ) was dissolved in $15 \mathrm{~mL}$ methanol. And $1.1 \mathrm{~mL}$ concentrated $\mathrm{H}_{2} \mathrm{SO}_{4}$ was added dropwise to the solution at $0{ }^{\circ} \mathrm{C}$, and then stirred overnight at $80{ }^{\circ} \mathrm{C}$ for $12 \mathrm{~h}$. When the mixture was cooled to room temperature, the solvent was removed by evaporation, and the residue was poured onto ice, perchloric acid $(70 \%, 2 \mathrm{~mL})$ was then added, and the resulting precipitate was filtered and purified by silica gel column chromatography $\left(\mathrm{CH}_{2} \mathrm{Cl}_{2} / \mathrm{MeOH}=30 / 1\right.$, v/v) to afford compound $\mathbf{C S O H}-\mathbf{C l}\left(701.6 \mathrm{mg}, 85.8 \%\right.$ yield) as a blue-purple solid. ${ }^{1} \mathrm{H}$ NMR $\left(400 \mathrm{MHz}, \mathrm{CDCl}_{3}\right) \delta 8.34(\mathrm{~d}, \mathrm{~J}=$ $13.5 \mathrm{~Hz}, 1 \mathrm{H}), 8.26(\mathrm{~d}, \mathrm{~J}=7.9 \mathrm{~Hz}, 1 \mathrm{H}), 7.76(\mathrm{t}, \mathrm{J}=7.5 \mathrm{~Hz}, 1 \mathrm{H}), 7.67$ (t, J = 7.7 Hz, 1H), 7.37 (s, 2H), 7.24 (d, J = 7.5 $\mathrm{Hz}, 1 \mathrm{H}), 7.16(\mathrm{t}, \mathrm{J}=7.5 \mathrm{~Hz}, 1 \mathrm{H}), 6.98(\mathrm{~d}, \mathrm{~J}=7.8 \mathrm{~Hz}, 1 \mathrm{H}), 6.94(\mathrm{~s}, 1 \mathrm{H}), 6.87(\mathrm{~s}, 1 \mathrm{H}), 5.76(\mathrm{~d}, \mathrm{~J}=13.4 \mathrm{~Hz}, 1 \mathrm{H}), 3.80$ (s, $3 \mathrm{H}), 3.49(\mathrm{~s}, 3 \mathrm{H}), 2.75-2.58(\mathrm{~m}, 2 \mathrm{H}), 2.28(\mathrm{~m}, 2 \mathrm{H}), 1.84(\mathrm{~s}, 2 \mathrm{H}), 1.76(\mathrm{~s}, 6 \mathrm{H}) .{ }^{13} \mathrm{C} \mathrm{NMR}\left(100 \mathrm{MHz}, \mathrm{CDCl}_{3}\right) \delta 168.2$, 165.9, 160.5, 156.9, 153.2, 143.7, 140.0, 136.2, 135.8, 133.1, 131.2, 131.0, 130.0, 129.6, 129.3, 129.0, 128.4, 126.0, 123.2, 122.7, 117.7, 116.5, 114.3, 108.6, 104.3, 95.9, 52.5, 48.5, 29.8, 28.7, 22.8, 21.1, 14.2. MS (ESI): calcd for $\left[\mathrm{C}_{34} \mathrm{H}_{31} \mathrm{ClNO}_{4}\right]^{+}=552.19$, found: 552.20 .

\section{Synthesis of Compound 2-SO ${ }_{3} \mathrm{~N}$}

The CSOH-Cl $(65.3 \mathrm{mg}, 0.17 \mathrm{mmol})$ and triethylamine $(150 \mu \mathrm{L})$ were dissolved in $5 \mathrm{~mL}$ dry dichloromethane at $0{ }^{\circ} \mathrm{C}$, and then a solution of 2,4-dinitrobenzenesulfonyl chloride $(115.3 \mathrm{mg}, 0.43 \mathrm{mmol})$ in dry dichloromethane was slowly added to it. The mixture was brought to room temperature and stirred for $4 \mathrm{~h}$. After the completion of the reaction, the reaction solvent was removed by rotary evaporation under reduced pressure, and the residue was purified by silica gel column chromatography (eluent, $\mathrm{CH}_{2} \mathrm{Cl}_{2} / \mathrm{MeOH}=30 / 1$, v/v) to obtain the product 2-SO $\mathbf{3} \mathbf{N}(30.1 \mathrm{mg}, 22.6 \%$ yield). ${ }^{1} \mathrm{H}$ NMR (400 MHz, $\left.\mathrm{CDCl}_{3}\right) \delta 8.67(\mathrm{~s}, 2 \mathrm{H}), 8.65(\mathrm{~s}, 1 \mathrm{H}), 8.44(\mathrm{~d}, \mathrm{~J}=8.4 \mathrm{~Hz}, 1 \mathrm{H}), 8.20(\mathrm{~d}, \mathrm{~J}=7.8 \mathrm{~Hz}, 1 \mathrm{H}), 7.72(\mathrm{dd}, \mathrm{J}$ $=15.6,8.0 \mathrm{~Hz}, 1 \mathrm{H}), 7.61(\mathrm{t}, \mathrm{J}=7.6 \mathrm{~Hz}, 1 \mathrm{H}), 7.52(\mathrm{~d}, \mathrm{~J}=6.6 \mathrm{~Hz}, 2 \mathrm{H}), 7.46(\mathrm{t}, \mathrm{J}=8.3 \mathrm{~Hz}, 2 \mathrm{H}), 7.38(\mathrm{~s}, 1 \mathrm{H}), 7.21(\mathrm{~d}, \mathrm{~J}=$ $7.5 \mathrm{~Hz}, 1 \mathrm{H}), 6.63$ (s, 1H), 6.59 (s, 1H), 4.00 (s, 3H), 3.77 (s, 3H), 2.70 (m, 2H), 2.30-2.17 (m, 2H), 1.78 (s, 6H), 0.90$0.82(\mathrm{~m}, 2 \mathrm{H})$. HRMS (ESI): calcd for $\left[\mathrm{C}_{40} \mathrm{H}_{33} \mathrm{ClN}_{3} \mathrm{O}_{10} \mathrm{~S}\right]^{+}=782.1570$, found: 782.1504 .

\section{Synthesis of Compound 3-CHO}

Compound o-carboxybenzaldehyde (450.3 mg, $3 \mathrm{mmol}$ ) was dissolved in $5 \mathrm{~mL}$ of anhydrous toluene, and thionyl chloride $(1.2 \mathrm{~mL})$ was added dropwise at $0{ }^{\circ} \mathrm{C}$. Then the mixture was transferred to an oil bath and heated at $110{ }^{\circ} \mathrm{C}$ under argon atmosphere for $6 \mathrm{~h}$. After the completion of the reaction, the reaction solvent was removed by rotary evaporation under reduced pressure and dried with a diaphragm pump. Next, the above reaction mixture was dissolved in $3 \mathrm{~mL}$ anhydrous $\mathrm{CH}_{2} \mathrm{Cl}_{2}$, and slowly added dropwise to the mixed solution of $\mathbf{C S O H}-\mathbf{C l}$ (110.3 $\left.\mathrm{mg}, 0.2 \mathrm{mmol}\right)$ and triethylamine $(150 \mu \mathrm{L})$ at $0{ }^{\circ} \mathrm{C}$. After reaction for $4 \mathrm{~h}$, the reaction solvent was removed by rotary evaporation under reduced pressure, and the residue was purified by a silica gel column (eluent, $\mathrm{CH}_{2} \mathrm{Cl}_{2} / \mathrm{MeOH}=30 / 1$, v/v) to obtain the product 3-CHO (21.6 mg, 15.5\% yield). ${ }^{1} \mathrm{H}$ NMR (400 MHz, DMSO-d6) $\delta 8.46$ (d, J = 15.3 Hz, 1H), 7.97 (d, J = 8.0 $\mathrm{Hz}, 1 \mathrm{H}), 7.82(\mathrm{~d}, \mathrm{~J}=7.8 \mathrm{~Hz}, 1 \mathrm{H}), 7.77(\mathrm{~d}, \mathrm{~J}=6.4 \mathrm{~Hz}, 2 \mathrm{H}), 7.67-7.63(\mathrm{~m}, 2 \mathrm{H}), 7.62-7.59(\mathrm{~m}, 2 \mathrm{H}), 7.57(\mathrm{~d}, \mathrm{~J}=5.2$ $\mathrm{Hz}, 1 \mathrm{H}), 7.53(\mathrm{~d}, \mathrm{~J}=4.0 \mathrm{~Hz}, 2 \mathrm{H}), 7.38(\mathrm{t}, \mathrm{J}=7.7 \mathrm{~Hz}, 1 \mathrm{H}), 7.31(\mathrm{t}, \mathrm{J}=7.5 \mathrm{~Hz}, 1 \mathrm{H}), 7.21(\mathrm{~d}, \mathrm{~J}=7.5 \mathrm{~Hz}, 1 \mathrm{H}), 6.53(\mathrm{~d}, \mathrm{~J}$ $=15.1 \mathrm{~Hz}, 1 \mathrm{H}), 6.42(\mathrm{~s}, 1 \mathrm{H}), 3.79(\mathrm{~s}, 3 \mathrm{H}), 3.51(\mathrm{~d}, \mathrm{~J}=5.1 \mathrm{~Hz}, 3 \mathrm{H}), 2.49(\mathrm{t}, \mathrm{J}=6.5 \mathrm{~Hz}, 2 \mathrm{H}), 2.12-1.89(\mathrm{~m}, 2 \mathrm{H}), 1.61$ $(\mathrm{s}, 6 \mathrm{H}), 0.64(\mathrm{~m} \mathrm{2H}) . . \mathrm{HRMS}(\mathrm{ESI})$ : calcd for $\left[\mathrm{C}_{42} \mathrm{H}_{35} \mathrm{ClNO}_{6}\right]^{+}=684.2147$, found: 684.2135 .

\section{Synthesis of Compound 4-Thia}

The CSOH-Cl $(54.7 \mathrm{mg}, 0.1 \mathrm{mmol})$ and triethylamine $(150 \mu \mathrm{L})$ were dissolved in $5 \mathrm{~mL}$ dry dichloromethane at $0{ }^{\circ} \mathrm{C}$, and then a solution of 2-thienyl chloride $(30.3 \mathrm{mg}, 0.2 \mathrm{mmol})$ in dry dichloromethane was slowly added to it. The 
mixture was brought to room temperature and stirred for $4 \mathrm{~h}$. After the completion of the reaction, the reaction solvent was removed by rotary evaporation under reduced pressure, and the residue was purified by silica gel column chromatography (eluent, $\mathrm{CH}_{2} \mathrm{Cl}_{2} / \mathrm{MeOH}=30 / 1$, v/v) to obtain the product 4-Thia (30.6 mg, 46.2\% yield). ${ }^{1} \mathrm{H} \mathrm{NMR}$ $\left(400 \mathrm{MHz}, \mathrm{CDCl}_{3}\right) \delta 8.74(\mathrm{~d}, \mathrm{~J}=15.2 \mathrm{~Hz}, 1 \mathrm{H}), 8.28(\mathrm{~d}, \mathrm{~J}=7.5 \mathrm{~Hz}, 1 \mathrm{H}), 8.10(\mathrm{~s}, 1 \mathrm{H}), 7.80(\mathrm{~s}, 2 \mathrm{H}), 7.69(\mathrm{t}, \mathrm{J}=7.0 \mathrm{~Hz}$, 1H), $7.52(\mathrm{~d}, \mathrm{~J}=6.2 \mathrm{~Hz}, 2 \mathrm{H}), 7.48(\mathrm{~d}, \mathrm{~J}=7.2 \mathrm{~Hz}, 2 \mathrm{H}), 7.38(\mathrm{~s}, 1 \mathrm{H}), 7.27(\mathrm{~s}, 2 \mathrm{H}), 6.79(\mathrm{~s}, 1 \mathrm{H}), 6.71$ (d, J = 14.9 Hz, $1 \mathrm{H}), 4.04(\mathrm{~s}, 3 \mathrm{H}), 3.84(\mathrm{~s}, 3 \mathrm{H}), 2.79(\mathrm{~m}, 2 \mathrm{H}), 2.37-2.25(\mathrm{~m}, 2 \mathrm{H}), 1.85(\mathrm{~s}, 6 \mathrm{H}), 0.91(\mathrm{~d}, \mathrm{~J}=6.1 \mathrm{~Hz}, 2 \mathrm{H}) .{ }^{13} \mathrm{C}$ NMR $(100$ $\left.\mathrm{MHz}, \mathrm{CDCl}_{3}\right) \delta 178.9,165.7,159.2,159.1,150.8,148.1,146.5,142.1,142.0,142.0,135.8,135.2,134.8,133.6,131.5$, 131.1, 129.9, 129.6, 129.4, 128.4, 128.0, 127.7, 126.7, 123.6, 122.3, 122.2, 116.5, 113.2, 111.7, 106.8, 52.5, 51.0, 29.7, 28.0, 23.7, 19.9, 14.1. HRMS (ESI): calcd for $\left[\mathrm{C}_{39} \mathrm{H}_{33} \mathrm{ClNO}_{5} \mathrm{~S}\right]^{+}=662.1768$, found: 662.1716 .

\section{Synthesis of Compound 5-BN 3}

Compound CSOH-Cl (82.4 mg, $0.15 \mathrm{mmol})$, anhydrous potassium carbonate $(138 \mathrm{mg}, 0.10 \mathrm{mmol})$ and benzyl bromide azide ( $145.3 \mathrm{mg}, 5 \mathrm{mmol}$ ) were dissolved in $8 \mathrm{~mL}$ of acetonitrile, and the temperature was increased at $80{ }^{\circ} \mathrm{C}$ for $12 \mathrm{~h}$. After the completion of the reaction, the reaction solvent was removed by rotary evaporation under reduced pressure, and the residue was purified by silica gel column chromatography (eluent, $\mathrm{CH}_{2} \mathrm{Cl}_{2} / \mathrm{MeOH}, 30 / 1$, v/v) to obtain the product 5-BN3 (40.4 mg, 39.3\% yield). ${ }^{1} \mathrm{H}$ NMR (400 MHz, $\left.\mathrm{CDCl}_{3}\right) \delta 8.78(\mathrm{~d}, \mathrm{~J}=14.8 \mathrm{~Hz}, 1 \mathrm{H}), 8.26(\mathrm{~d}, \mathrm{~J}$ $=7.8 \mathrm{~Hz}, 1 \mathrm{H}), 7.78(\mathrm{t}, \mathrm{J}=7.4 \mathrm{~Hz}, 1 \mathrm{H}), 7.68(\mathrm{~d}, \mathrm{~J}=7.6 \mathrm{~Hz}, 1 \mathrm{H}), 7.63(\mathrm{~d}, \mathrm{~J}=8.3 \mathrm{~Hz}, 2 \mathrm{H}), 7.58(\mathrm{~d}, \mathrm{~J}=7.4 \mathrm{~Hz}, 1 \mathrm{H}), 7.47$ $(\mathrm{d}, \mathrm{J}=7.7 \mathrm{~Hz}, 1 \mathrm{H}), 7.39$ (t, J = 6.2 Hz, 2H), $7.29(\mathrm{~s}, 1 \mathrm{H}), 7.22(\mathrm{~d}, \mathrm{~J}=7.5 \mathrm{~Hz}, 1 \mathrm{H}), 7.07$ (d, J = 8.2 Hz, 2H), 6.73 (s, 1H), $6.37(\mathrm{~d}, \mathrm{~J}=14.8 \mathrm{~Hz}, 1 \mathrm{H}), 5.43(\mathrm{~d}, \mathrm{~J}=10.6 \mathrm{~Hz}, 2 \mathrm{H}), 3.94(\mathrm{~s}, 3 \mathrm{H}), 3.79(\mathrm{~s}, 3 \mathrm{H}), 2.69(\mathrm{~m}, 2 \mathrm{H}), 2.32-2.25(\mathrm{~m}, 2 \mathrm{H})$, 1.87 (s, 6H), 1.84-1.79 (m, 2H). ${ }^{13} \mathrm{C}$ NMR (100 MHz, $\left.\mathrm{CDCl}_{3}\right) \delta 178.2,165.8,161.3,157.1,152.6,146.4,145.5,142.4$, $141.8,139.8,139.4,135.7,133.6,132.8,131.5,129.8,129.6,129.4,129.1,127.4,126.5,125.0,122.8,121.0,119.3$, 117.1, 115.5, 112.4, 103.7, 102.0, 71.2, 52.6, 51.0, 29.8, 27.9, 22.8, 14.2. HRMS (ESI): calcd for $\left[\mathrm{C}_{41} \mathrm{H}_{36} \mathrm{ClN}_{4} \mathrm{O}_{4}\right]^{+}=$ 683.2420, found: 683.2338 .

\section{Synthesis of Compound 6-NBD}

The CSOH-Cl $(75.3 \mathrm{mg}, 0.13 \mathrm{mmol})$ and triethylamine $(100 \mu \mathrm{L})$ were dissolved in $5 \mathrm{~mL}$ dry dichloromethane at $0{ }^{\circ} \mathrm{C}$, and then a solution of 4-chloro-7-nitrobenzofurazan $(40.1 \mathrm{mg}, 0.15 \mathrm{mmol})$ in dry dichloromethane was slowly added to it. The mixture was brought to room temperature and stirred for $6 \mathrm{~h}$. After the completion of the reaction, the reaction solvent was removed by rotary evaporation under reduced pressure, and the residue was purified by silica gel column chromatography (eluent, $\mathrm{CH}_{2} \mathrm{Cl}_{2} / \mathrm{MeOH}=30 / 1$, v/v) to obtain the product 6-NBD (30.6 mg, 32.3\% yield). ${ }^{1} \mathrm{H}$ $\operatorname{NMR}\left(400 \mathrm{MHz}, \mathrm{CDCl}_{3}\right) \delta 8.71(\mathrm{~d}, \mathrm{~J}=12.6 \mathrm{~Hz}, 1 \mathrm{H}), 8.52(\mathrm{~s}, 1 \mathrm{H}), 8.24(\mathrm{~d}, \mathrm{~J}=7.7 \mathrm{~Hz}, 1 \mathrm{H}), 7.77(\mathrm{~d}, \mathrm{~J}=6.6 \mathrm{~Hz}, 1 \mathrm{H})$, $7.66(\mathrm{~d}, \mathrm{~J}=7.6 \mathrm{~Hz}, 1 \mathrm{H}), 7.53$ (s, 2H), $7.45(\mathrm{~d}, \mathrm{~J}=6.5 \mathrm{~Hz}, 3 \mathrm{H}), 7.10(\mathrm{~d}, \mathrm{~J}=8.8 \mathrm{~Hz}, 1 \mathrm{H}), 6.85(\mathrm{~d}, \mathrm{~J}=7.2 \mathrm{~Hz}, 1 \mathrm{H}), 6.79$ $(\mathrm{d}, \mathrm{J}=4.4 \mathrm{~Hz}, 2 \mathrm{H}), 4.13(\mathrm{~s}, 3 \mathrm{H}), 3.82(\mathrm{~s}, 3 \mathrm{H}), 2.84-2.69(\mathrm{~m}, 2 \mathrm{H}), 2.35-2.28(\mathrm{~m}, 2 \mathrm{H}), 1.75(\mathrm{~s}, 6 \mathrm{H}), 1.61-1.55(\mathrm{~m}$, $2 \mathrm{H})$. HRMS (ESI): calcd for $\left[\mathrm{C}_{40} \mathrm{H}_{32} \mathrm{ClN}_{4} \mathrm{O}_{7}\right]^{+}=715.1954$, found: 715.1938 . 


\section{Spectra and biological studies}

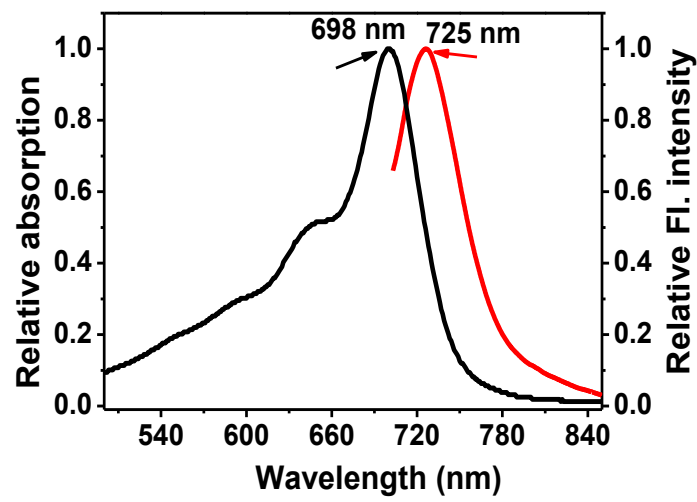

Figure. S1. Absorption and fluorescence spectra of fluorophore CS-OH-Cl in PBS buffer $(25 \mathrm{mM}, \mathrm{pH} 7.4$, containing $20 \%$ ethanol). $\lambda_{\mathrm{ex}}=660 \mathrm{~nm}$.

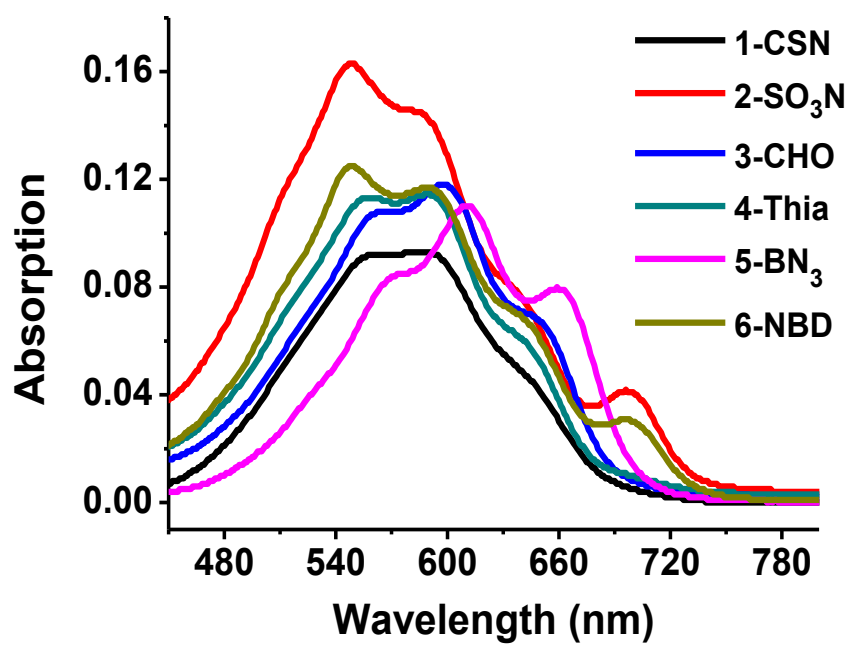

Figure. S2. Absorption spectra of $5 \mu \mathrm{M}$ compounds 1-CSN, 2-SO $3 \mathbf{N}, 3-\mathbf{C H O}, 4-\mathrm{Thia}, 5-\mathbf{B N}_{3}$ and 6-NBD in PBS buffer ( $25 \mathrm{mM}$, pH 7.4, containing $20 \%$ ethanol). 

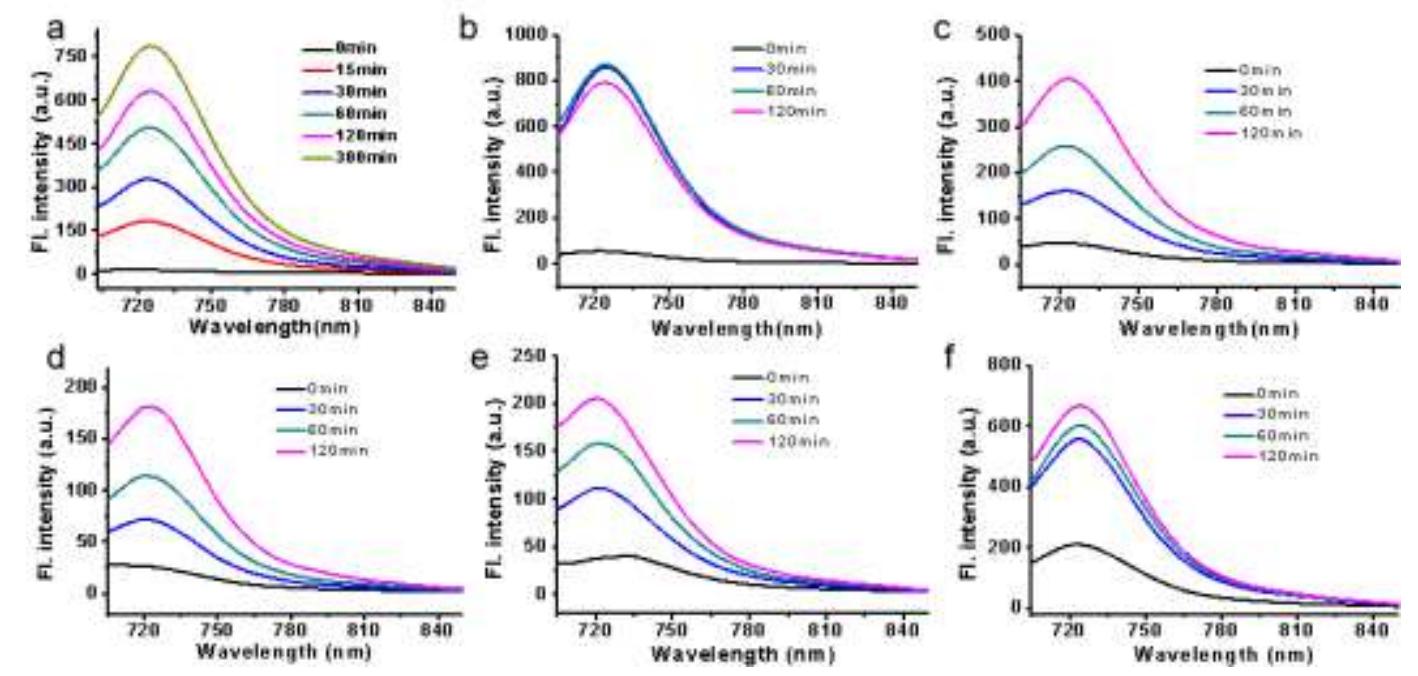

Figure. S3. The fluorescence spectra of $5 \mu \mathrm{M}$ compounds 1-CSN (a), 2-SO $\mathbf{S}_{3} \mathbf{N}$ (b), 3-CHO (c), 4-Thia (d), 5-BN $\mathbf{B}_{3}$ (e), 6-NBD (f) in the presence of $100 \mu \mathrm{M} \mathrm{Na} 2 \mathrm{~S}$ with different time in PBS buffer ( $25 \mathrm{mM}, \mathrm{pH} 7.4$, containing $20 \%$ ethanol) at $37^{\circ} \mathrm{C} . \lambda_{\mathrm{ex}}=660 \mathrm{~nm}$.
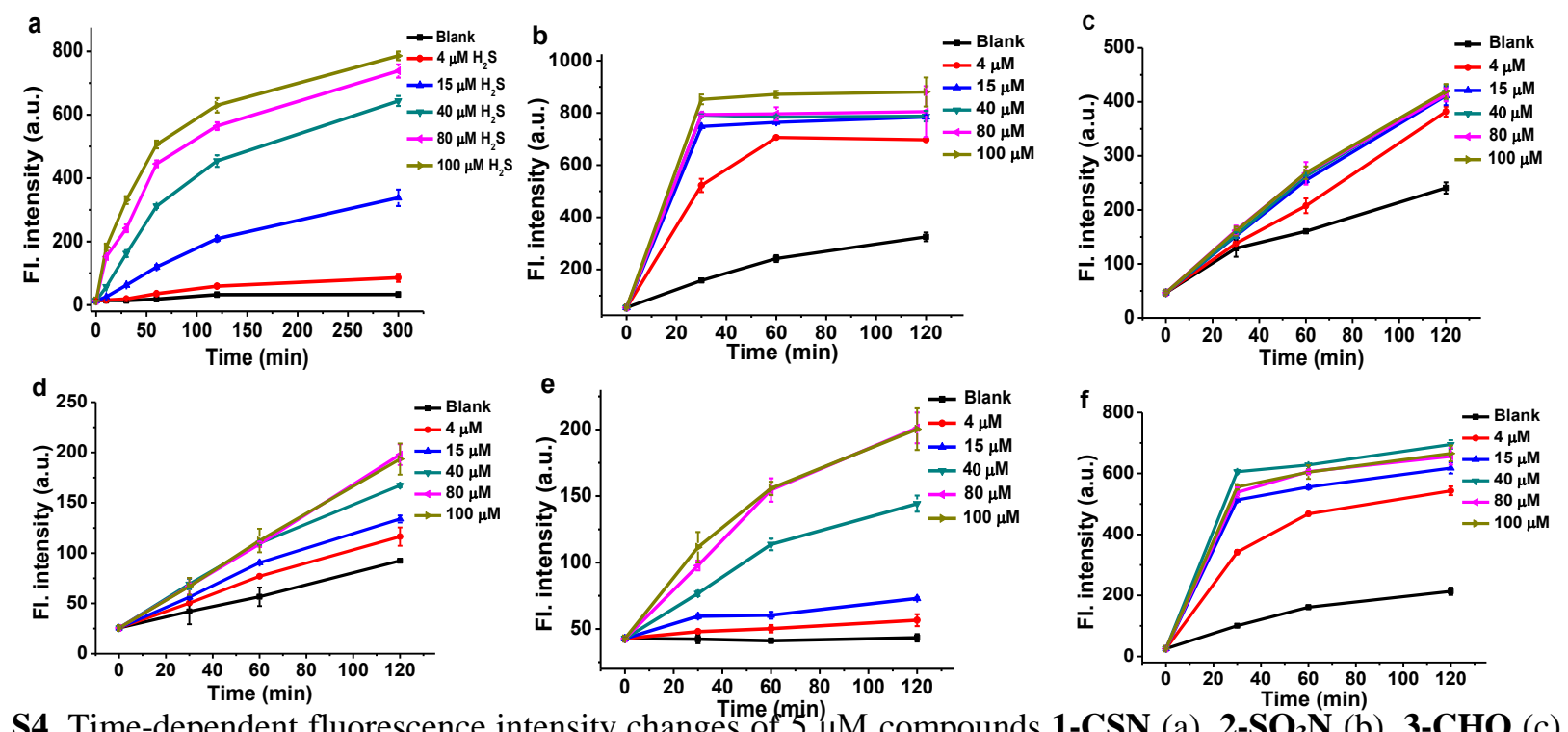

Figure. S4. Time-dependent fluorescence intensity changes of $5^{2} \mu \mathrm{M}$ compounds 1-CSN (a), 2-SO $\mathbf{S}_{3} \mathbf{N}$ (b), 3-CHO (c),

4-Thia (d), 5-BN 3 (e), 6-NBD (f) in the presence of various concentrations of $\mathrm{Na}_{2} \mathrm{~S}(0,4,15,40,80,100 \mu \mathrm{M}$, respectively) in PBS buffer $(25 \mathrm{mM}, \mathrm{pH} 7.4$, containing $20 \%$ ethanol $)$ at $37{ }^{\circ} \mathrm{C} . \lambda_{\mathrm{ex}} / \lambda_{\mathrm{em}}=660 / 725 \mathrm{~nm}$. 

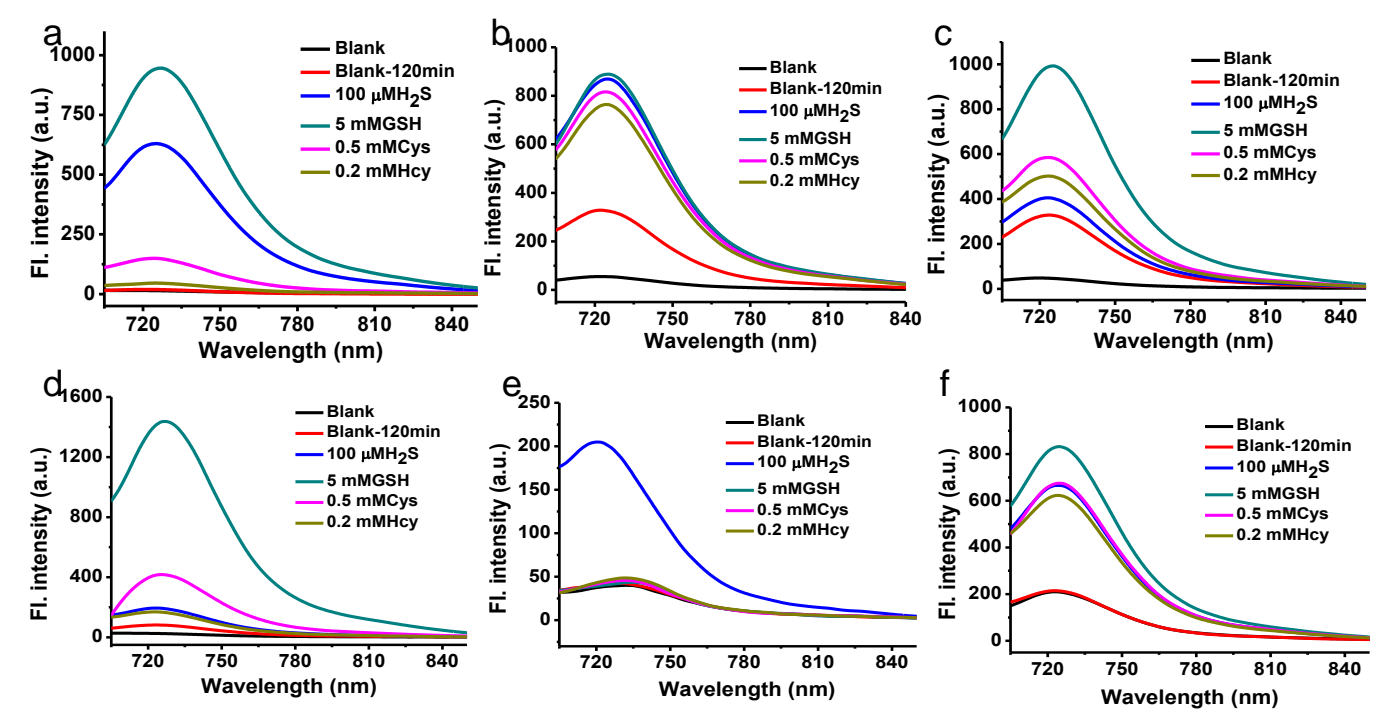

Figure. S5. Fluorescence response of compounds 1-CSN (a), 2-SO $3 \mathbf{N}$ (b), 3-CHO (c), 4-Thia (d), 5-BN3 (e), 6-NBD (f) to the common active sulfur species in PBS buffer $(25 \mathrm{mM}, \mathrm{pH} 7.4$, containing $20 \%$ ethanol $)$ at $37^{\circ} \mathrm{C}$. $\lambda_{\mathrm{ex}}=660 \mathrm{~nm}$.
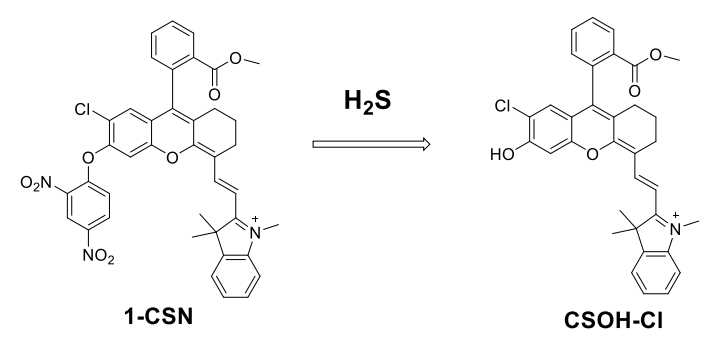

Exact Mass: 718.20

Exact Mass: 552.19

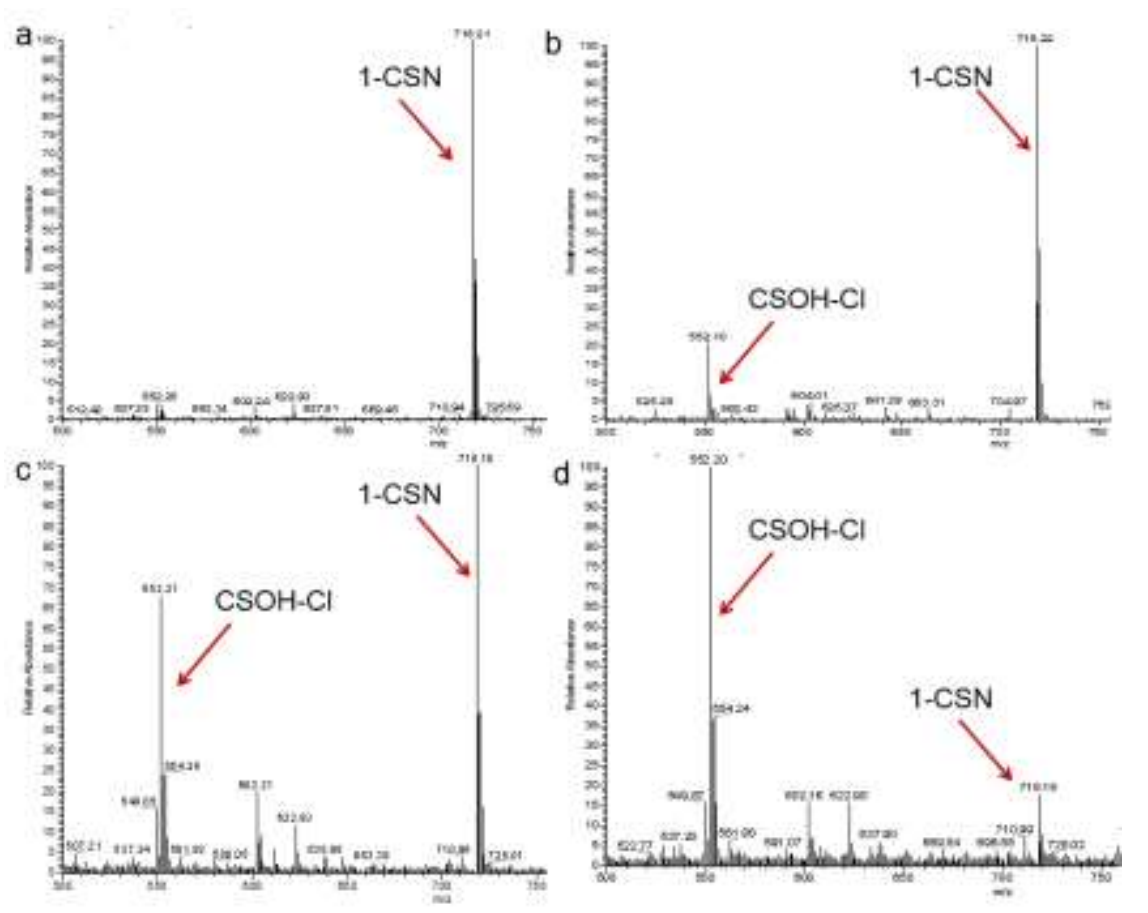

Figure. S6. The ESI mass spectrum of probe 1-CSN in the presence of $0 \mu \mathrm{M} \mathrm{Na} a_{2} \mathrm{~S}$ (a), $10 \mu \mathrm{M} \mathrm{Na}{ }_{2} \mathrm{~S}$ (b), $40 \mu \mathrm{M} \mathrm{Na} \mathrm{Na}_{2} \mathrm{~S}$ (c), $100 \mu \mathrm{M} \mathrm{Na} 2 \mathrm{~S}$ (d) after 120 minutes of reaction. As the concentration of $\mathrm{H}_{2} \mathrm{~S}$ increases, the signal peak of dye (CSOH-Cl) appears and gradually increases, while the probe signal peak (1-CSN) gradually decreases. 

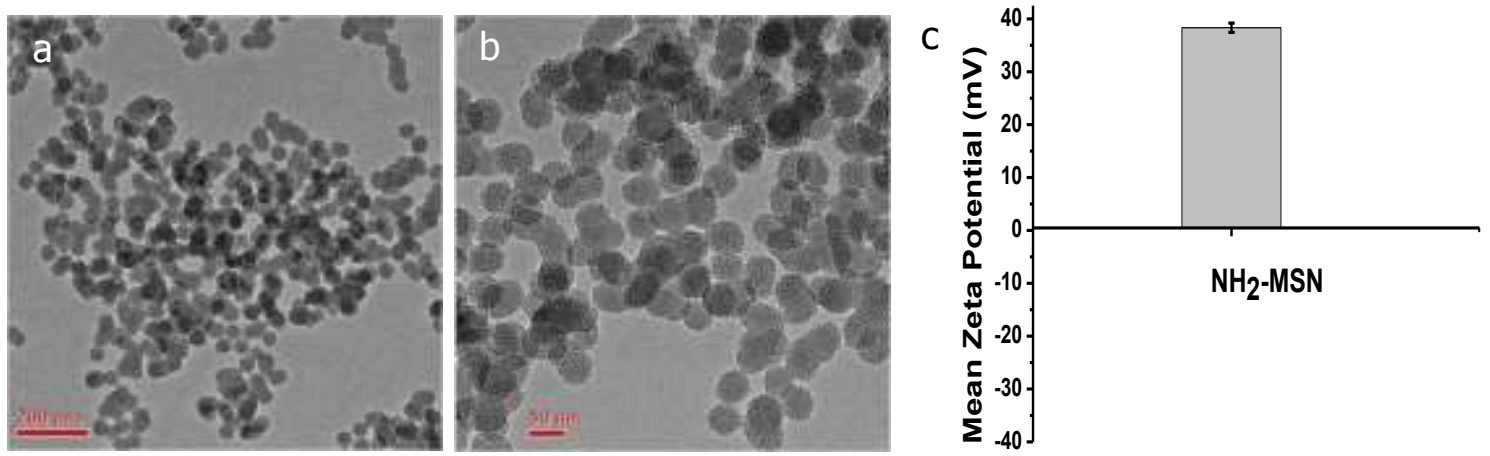

Figure. S7. TEM images of the amino-functionalized MSN (MSN-NH2), the scale bar are $100 \mathrm{~nm}$ (a) and $50 \mathrm{~nm}$ (b), respectively. (c) The mean zeta potential of $\mathbf{M S N}-\mathbf{N H}_{2}$ in $\mathrm{H}_{2} \mathrm{O}$.
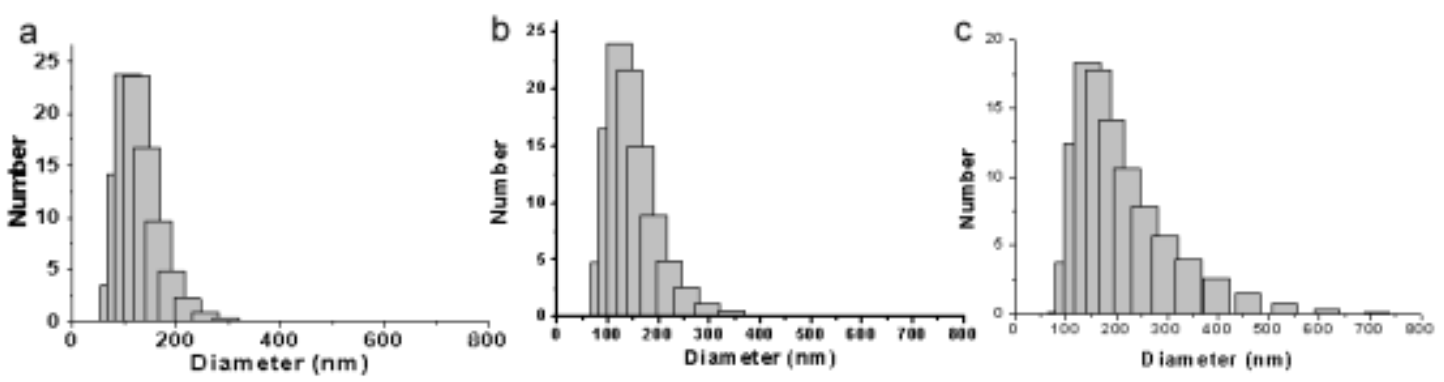

Figure. S8. The average hydrodynamic size of MSN-NH2 (a), MSN@CSN (b), MSN@CSN@PEG (c) measured by dynamic light scattering (DLS).

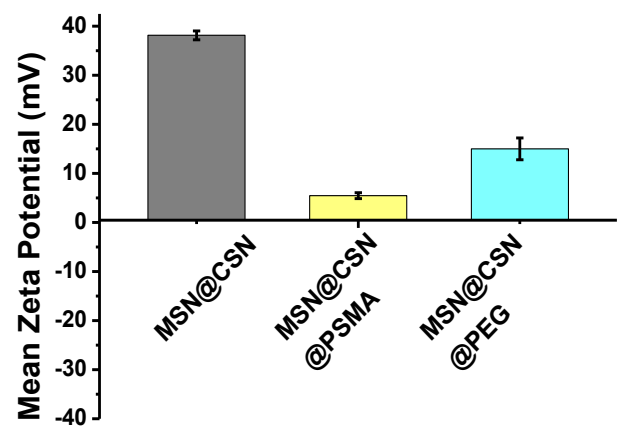

Figure. S9. The mean zeta potential of MSN@CSN, MSN@CSN@PSMA, MSN@CSN@PEG in $\mathrm{H}_{2} \mathrm{O}$. 

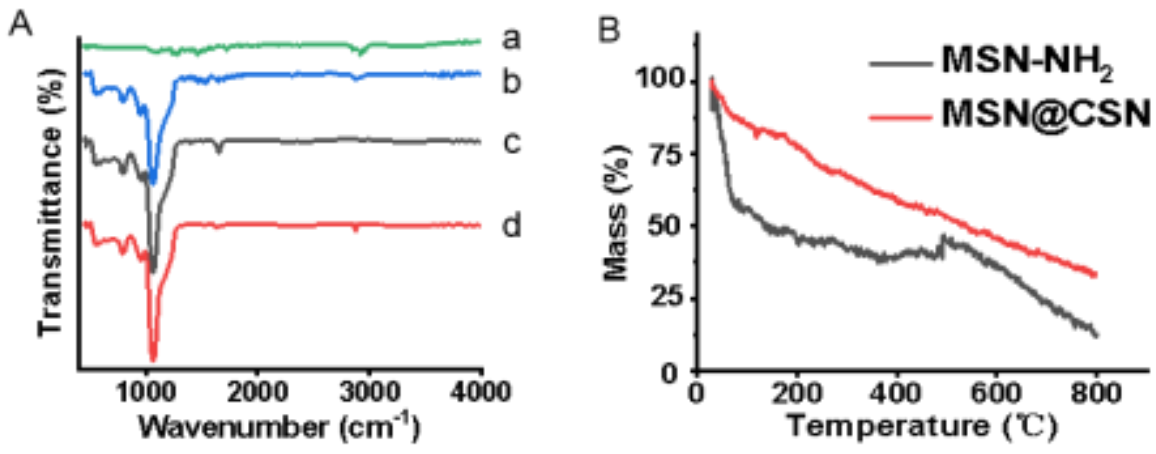

Figure. S10. (A) FT-IR spectra of (a) CSN-1, (b) MSN@CSN, (c) MSN-NH2, (d) MSN@CSN@PEG. (B) Thermogravimetric analysis (TGA) data for MSN-NH2 and MSN@CSN.
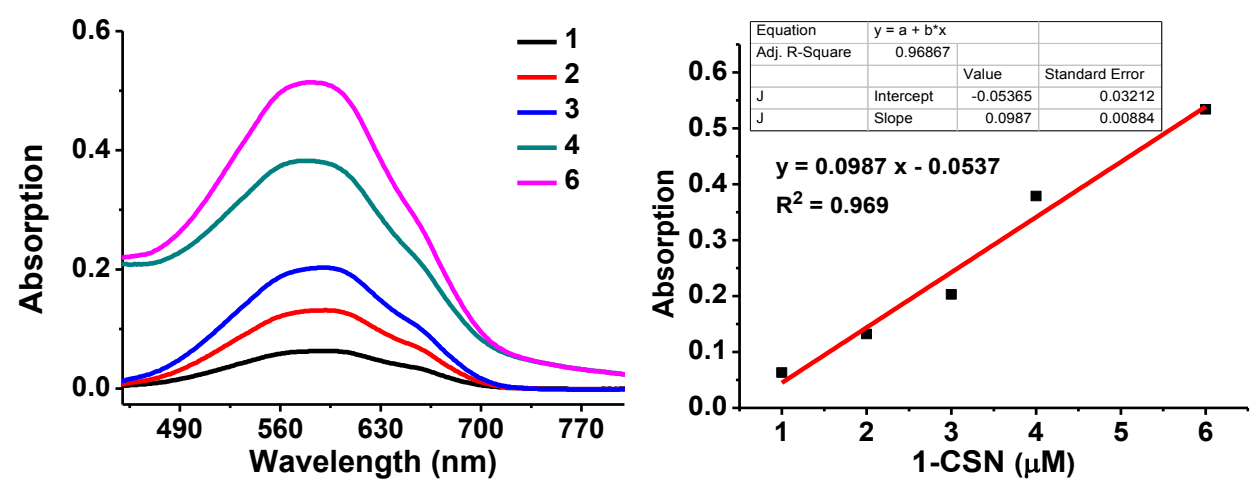

Figure. S11. The absorption spectra of different concentrations $(1,2,3,4,6 \mu \mathrm{M})$ of the small molecule probe 1-CSN in ethanol and its linear relationship between the UV-absorbance and concentration.

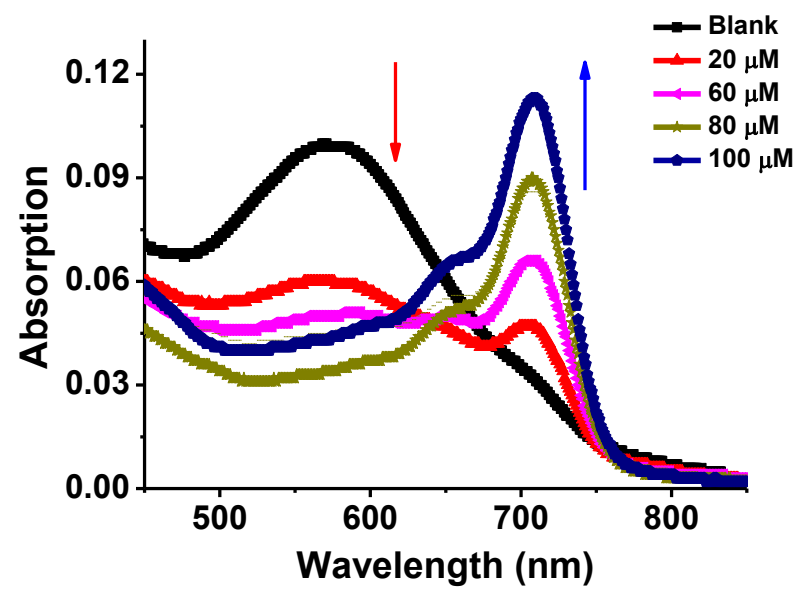

Figure. S12. Absorption spectrum of NIR fluorescent nanoprobe MSN@CSN@PEG (200 $\mu \mathrm{g} / \mathrm{mL})$ in the presence of various concentrations of $\mathrm{Na}_{2} \mathrm{~S}(0,20,60,80,100 \mu \mathrm{M}$, respectively) in $25 \mathrm{mM}$ PBS buffer (pH 7.4, contains $10 \%$ ethanol) at $37^{\circ} \mathrm{C}$. 

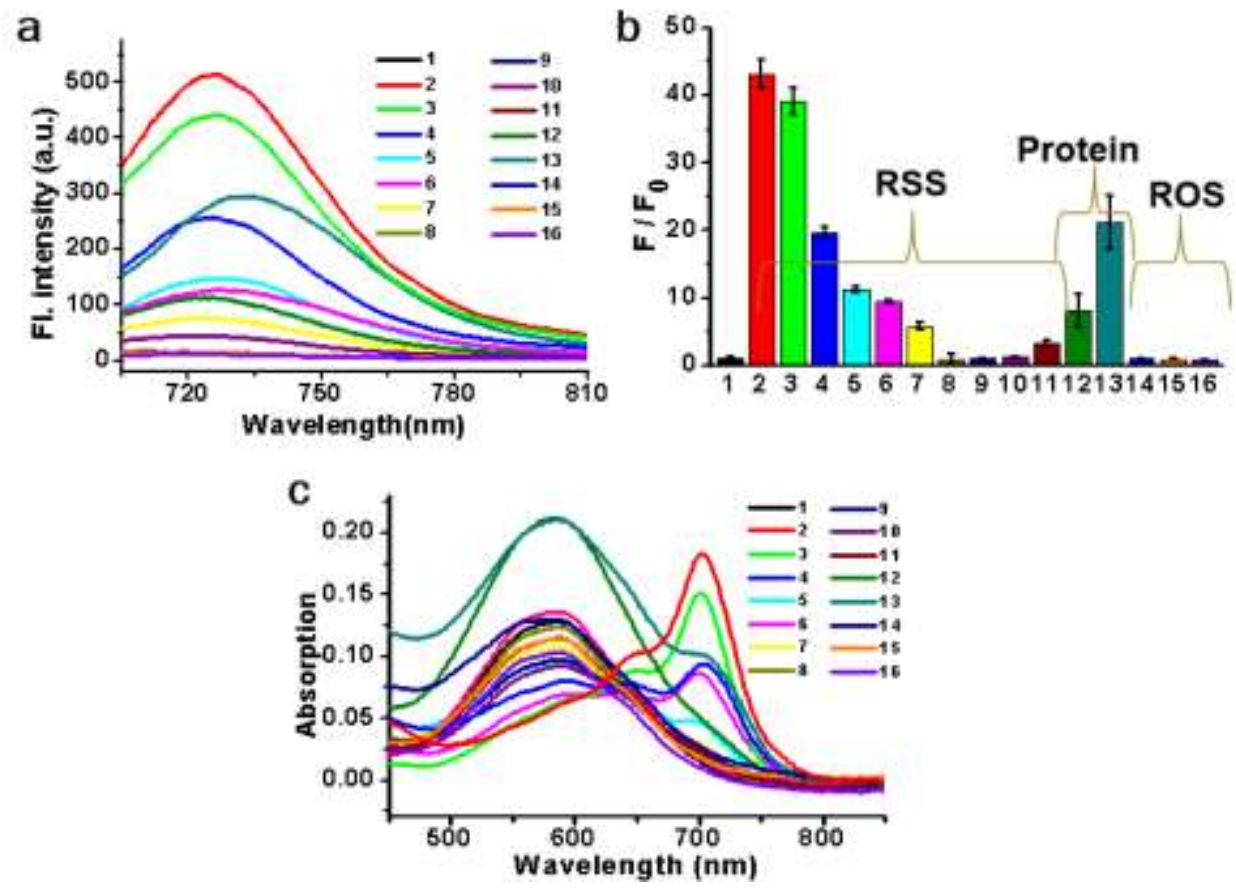

Figure. S13. The fluorescence spectrum (a), fluorescence ratio changes (b) and absorption spectrum (c) of NIR fluorescent probe 1-CSN $(5 \mu \mathrm{M})$ in the presence of $\mathrm{Na}_{2} \mathrm{~S}$ and other biomolecules ((1) blank, (2) $100 \mu \mathrm{M} \mathrm{Na} 2 \mathrm{~S}$, (3) 5 mM GSH, (4) 0.5 mM Cys, (5) $0.2 \mathrm{mM} \mathrm{Hcy,} \mathrm{(6)} 50 \mu \mathrm{M} \mathrm{Na}_{2} \mathrm{~S}_{2}$, (7) $200 \mu \mathrm{M} \mathrm{NaHSO}_{3}$, (8) $200 \mu \mathrm{M} \mathrm{Na}_{2} \mathrm{SO}_{3}$, (9) 200 $\mu \mathrm{M} \mathrm{Na}_{2} \mathrm{~S}_{2} \mathrm{O}_{3}$, (100) $200 \mu \mathrm{M} \mathrm{NaSCN}$, (11) $50 \mu \mathrm{M}$ Se-Cys, (12) $300 \mu \mathrm{M}$ BSA, (13) $300 \mu \mathrm{M}$ HSA, (14) $100 \mu \mathrm{M} \mathrm{H}_{2} \mathrm{O}_{2}$, (15) $100 \mu \mathrm{M} \mathrm{KO}_{2}$, (16) $30 \mu \mathrm{M} \mathrm{HClO).} F$ and $F_{0}$ represent the fluorescence intensity at $725 \mathrm{~nm}$ in the presence and absence of analyte, respectively. $\lambda_{\mathrm{ex}} / \lambda_{\mathrm{em}}=660 / 725 \mathrm{~nm}$.

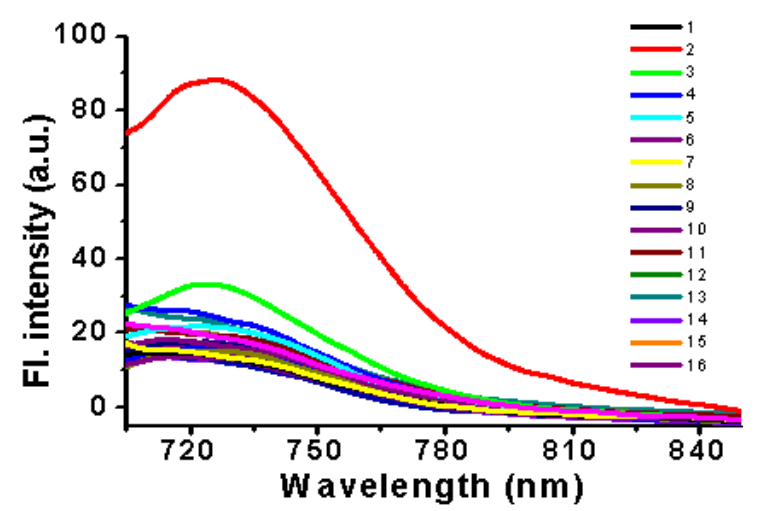

Figure. S14. The fluorescence spectrum of NIR fluorescent nanoprobe MSN@CSN@PEG $(200 \mu \mathrm{g} / \mathrm{mL})$ in the presence of $\mathrm{Na}_{2} \mathrm{~S}$ and other biomolecules ((1) blank, (2) $100 \mu \mathrm{M} \mathrm{Na}{ }_{2} \mathrm{~S}$, (3) $5 \mathrm{mM} \mathrm{GSH}$, (4) $0.5 \mathrm{mM} \mathrm{Cys,} \mathrm{(5)} 0.2$ mM Hcy, (6) $50 \mu \mathrm{M} \mathrm{Na}_{2} \mathrm{~S}_{2}$, (7) $200 \mu \mathrm{M} \mathrm{NaHSO}_{3}$, (8) $200 \mu \mathrm{M} \mathrm{Na}_{2} \mathrm{SO}_{3}$, (9) $200 \mu \mathrm{M} \mathrm{Na}_{2} \mathrm{~S}_{2} \mathrm{O}_{3}$, (100) $200 \mu \mathrm{M} \mathrm{NaSCN}$, (11) $50 \mu \mathrm{M}$ Se-Cys, (12) $300 \mu \mathrm{M}$ BSA, (13) $300 \mu \mathrm{M}$ HSA, (14) $100 \mu \mathrm{M} \mathrm{H}_{2} \mathrm{O}_{2}$, (15) $100 \mu \mathrm{M} \mathrm{KO}$, (16) $30 \mu \mathrm{M}$ $\mathrm{HClO}) . \lambda_{\mathrm{ex}}=660 \mathrm{~nm}$. 

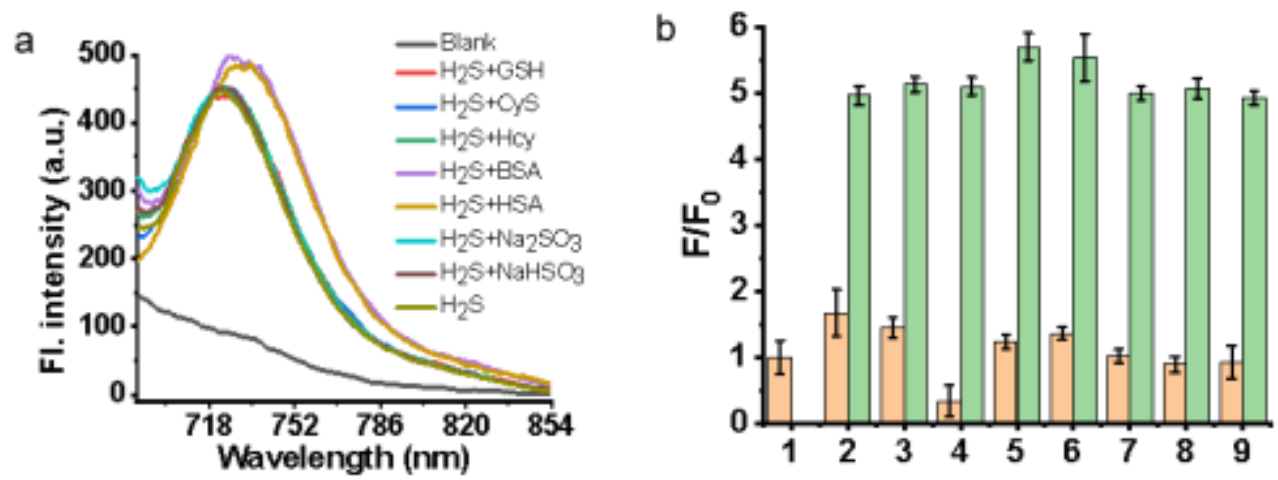

Figure. S15. Fluorescence spectra (a) and the change of fluorescent intensity at $729 \mathrm{~nm}$ (b) for $\mathrm{H}_{2} \mathrm{~S}$ detection by using nanoprobe MSN@CSN@PEG (200 $\mu \mathrm{g} / \mathrm{mL})$ in the presence of various RSS ((1) blank, (2) $5 \mathrm{mM} \mathrm{GSH,} \mathrm{(3)}$ $0.5 \mathrm{mM}$ Cys, (4) $0.2 \mathrm{mM}$ Hcy, (5) $300 \mu \mathrm{M}$ BSA, (6) $300 \mu \mathrm{M}$ HSA, (7) $200 \mu \mathrm{M} \mathrm{Na}_{2} \mathrm{SO}_{3}$, (8) $200 \mu \mathrm{M} \mathrm{NaHSO}$, (9) $100 \mu \mathrm{M} \mathrm{H}_{2} \mathrm{~S}$ ). Orange bars and cyan bars represent the changes in fluorescence intensity before and after adding $\mathrm{H}_{2} \mathrm{~S}$, respectively. All experiments were performed in $25 \mathrm{mM}$ PBS buffer (pH 7.4, contains $10 \%$ ethanol) at $37{ }^{\circ} \mathrm{C}$ and data was obtained $120 \mathrm{~min}$ after addition of each analyte. $\lambda_{\mathrm{ex}} / \lambda_{\mathrm{em}}=660 / 729 \mathrm{~nm}$.

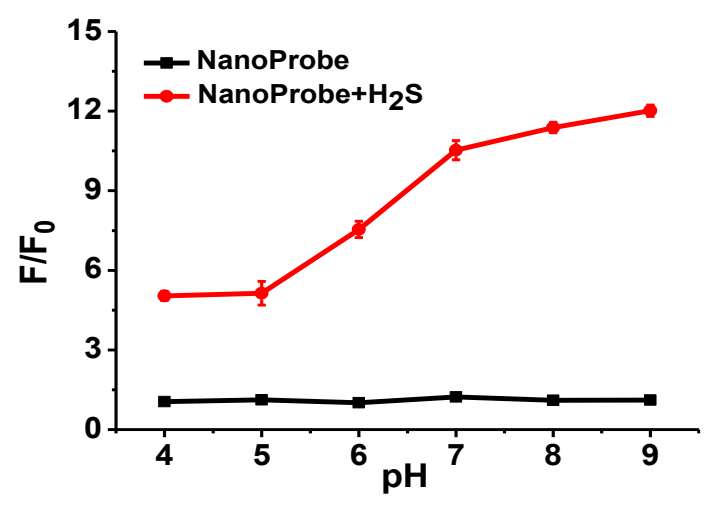

Figure. S16. Fluorescence response of nanoprobe MSN@CSN@PEG with $100 \mu \mathrm{M} \mathrm{H}_{2} \mathrm{~S}$ in PBS buffer solutions (containing $10 \%$ ethanol) of different $\mathrm{pH}$. $F$ and $F_{0}$ represent the fluorescence intensity at $729 \mathrm{~nm}$ in the presence and absence of $\mathrm{Na}_{2} \mathrm{~S}$, respectively. $\lambda_{\mathrm{ex}}=660 \mathrm{~nm}$.

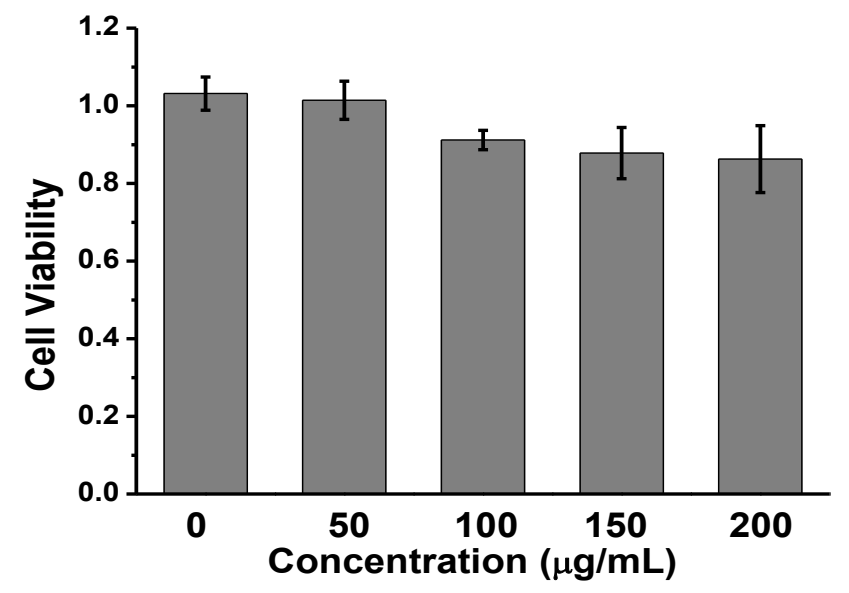

Figure. S17. The cytotoxicity of nanoprobe MSN@CSN@PEG in normal liver cells (HL-7702). 
a

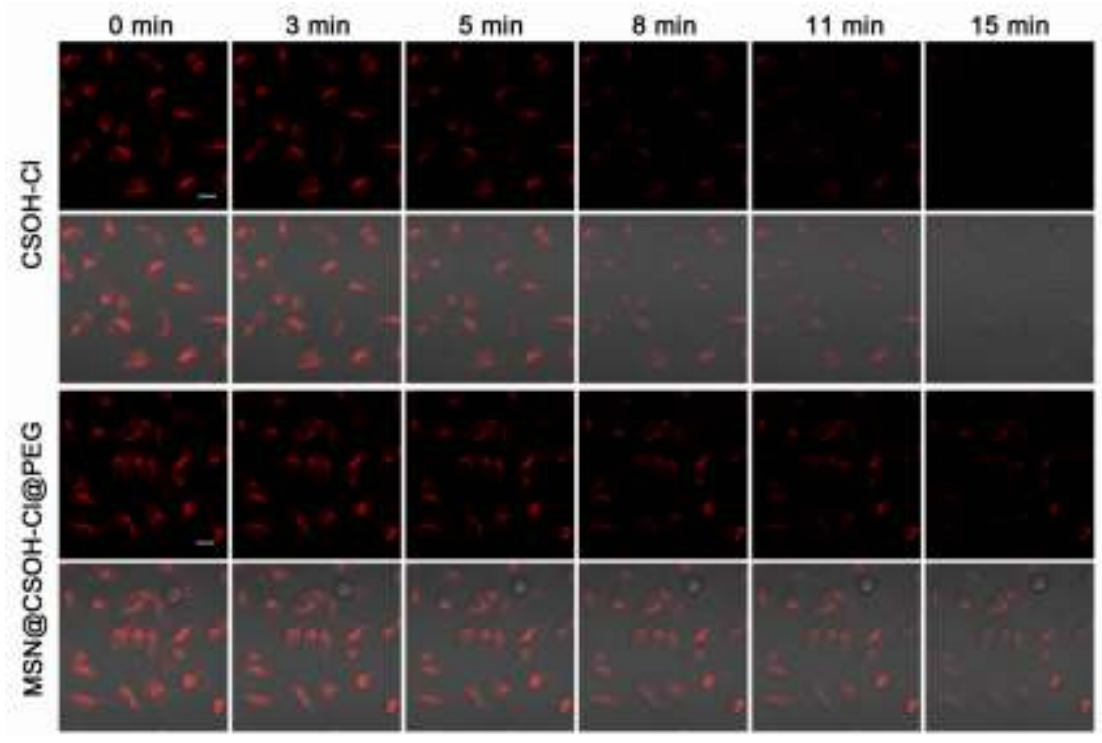

b

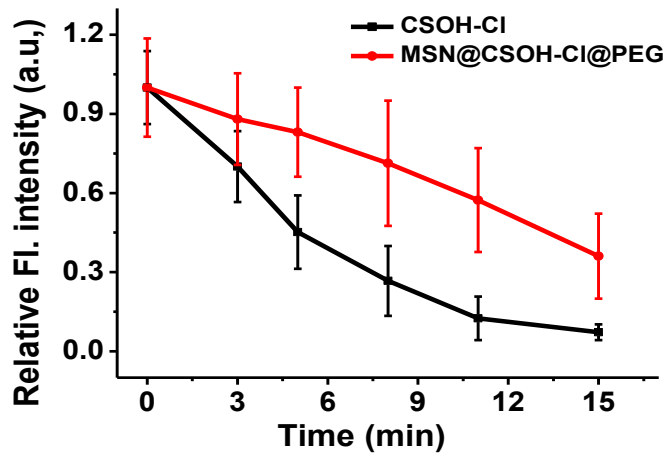

Figure. S18. (a) The photostability of the same concentration of fluorophore CSOH-Cl and MSN@CSOH-CI@PEG in HL-7702 cells under continuous irradiation with the same parameters of confocal microscope. Scale bar: $20 \mu \mathrm{m}$. (b) Quantification of the relative mean fluorescence intensity of cells from (a). $\lambda_{\mathrm{ex}}=640 \mathrm{~nm}, \lambda_{\mathrm{em}}=660-738 \mathrm{~nm}$.

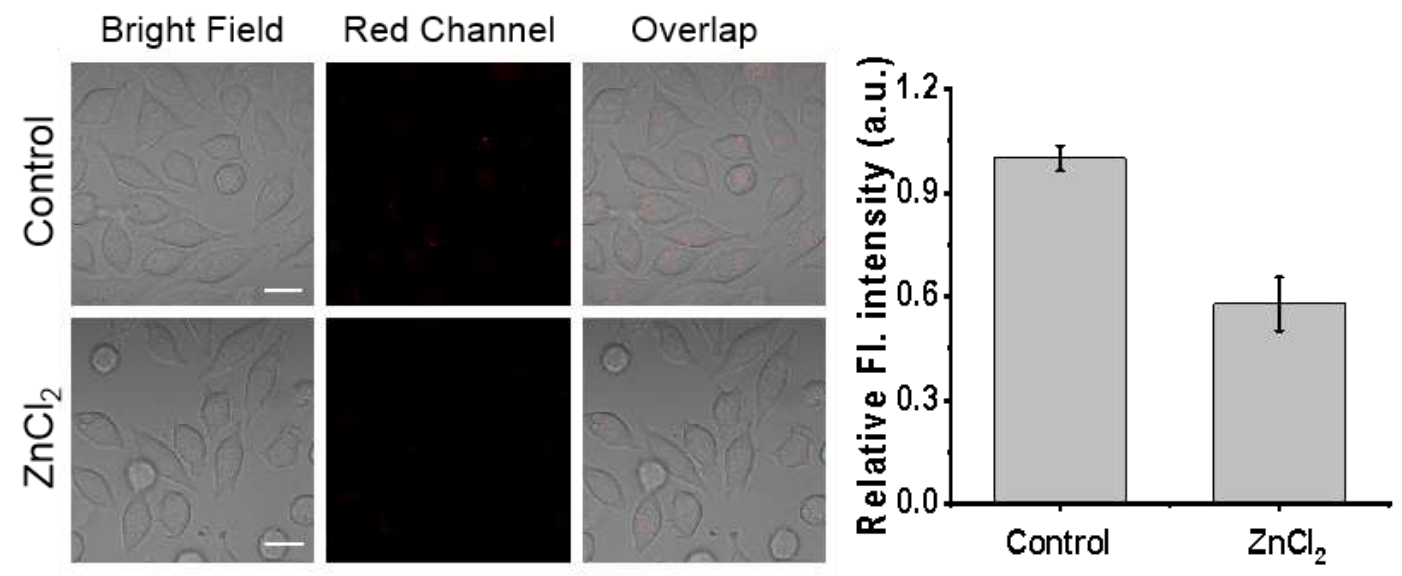

Figure. S19. Confocal microscopy images of live HL-7702 cells using nanoprobe MSN@CSN@PEG (100 $\mu \mathrm{g} / \mathrm{mL})$. cells were untreated (control) or pretreated with $\mathrm{ZnCl}_{2}(100 \mu \mathrm{M})$ for $20 \mathrm{~min}$, then incubated with nanoprobe for $2 \mathrm{~h}$ prior imaging. Relative fluorescence intensity of red channel were acquired from cells. Data represent mean standard error ( $\mathrm{n}=3$ independent experiments). $\lambda_{\mathrm{ex}}=640 \mathrm{~nm}, \lambda_{\mathrm{em}}=660-738 \mathrm{~nm}$. Scale bar: $20 \mu \mathrm{m}$. 


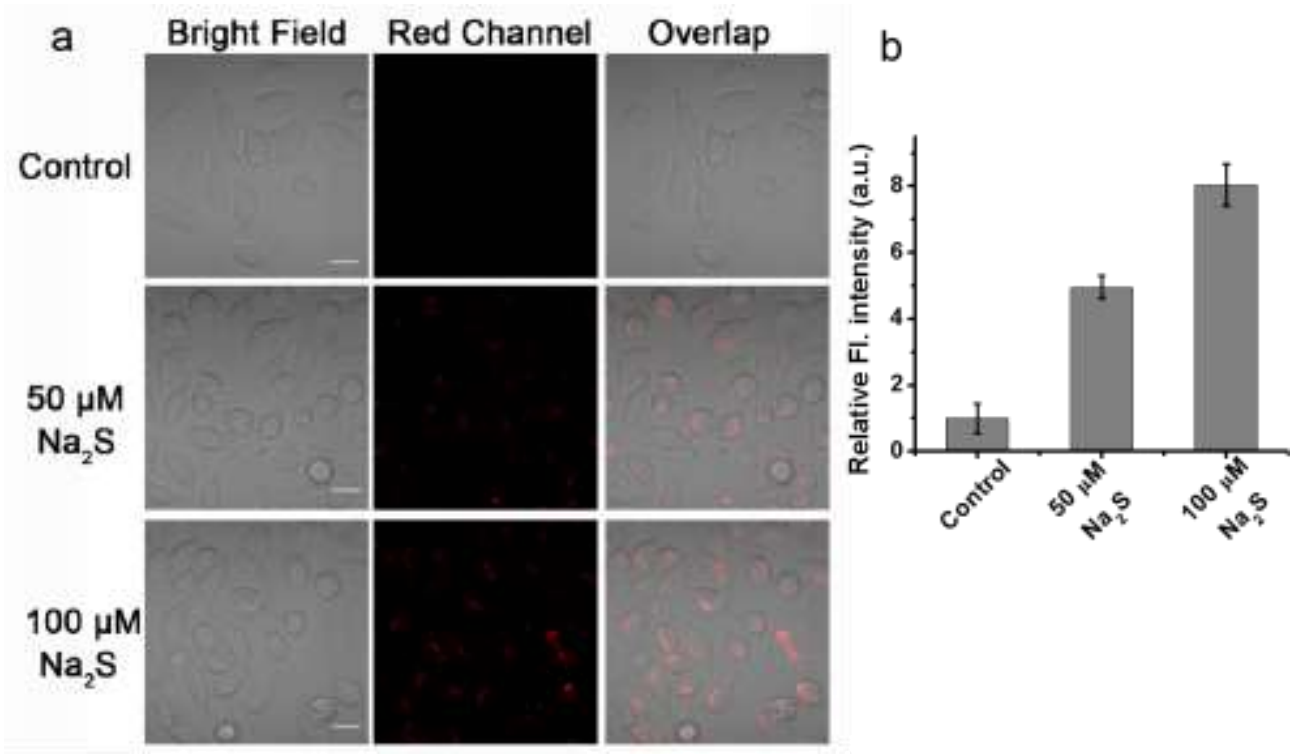

Figure. S20. (a) Confocal microscopy images of $\mathrm{H}_{2} \mathrm{~S}$ in live HL-7702 cells using nanoprobe MSN@CSN@PEG (100 $\mu \mathrm{g} / \mathrm{mL})$. First row: cells incubated with MSN@CSN@PEG for $2 \mathrm{~h}$ prior imaging; Second to third rows: cells incubated with MSN@CSN@PEG for $2 \mathrm{~h}$, then 50 or $100 \mu \mathrm{M} \mathrm{Na} 2 \mathrm{~S}$ loaded for another $1.5 \mathrm{~h}$ prior imaging. (b) Relative fluorescence intensity of red channel in cells were acquired from (a). Data represent mean standard error ( $\mathrm{n}=3$ independent experiments). $\lambda_{\mathrm{ex}}=640 \mathrm{~nm}, \lambda_{\mathrm{em}}=660-738 \mathrm{~nm}$. Scale bar: $20 \mu \mathrm{m}$.

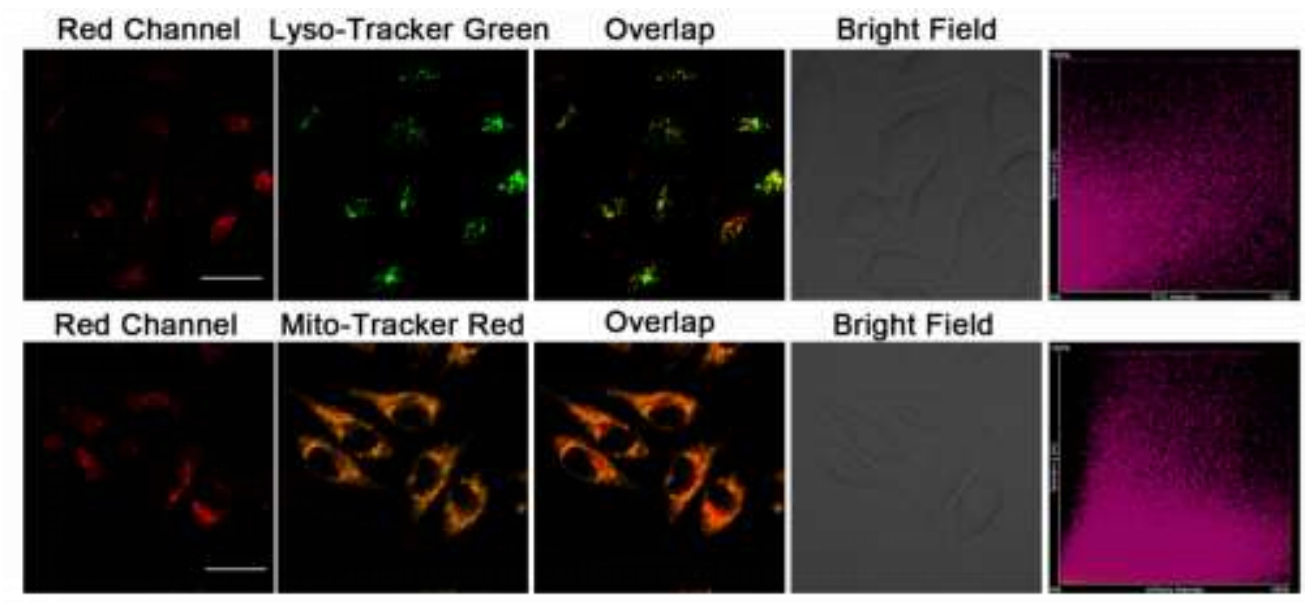

Figure. 21. The colocalization of nanoprobe MSN@CSN@PEG $(100 \mu \mathrm{g} / \mathrm{mL})$ in HL-7702 cells when treated with $100 \mu \mathrm{M}$ $\mathrm{Na}_{2} \mathrm{~S}$. Red Channel: $\lambda_{\mathrm{ex}}=640 \mathrm{~nm}, \lambda_{\mathrm{em}}=660-738 \mathrm{~nm}$. Lyso-tracker Green $(0.1 \mu \mathrm{M}, 15 \mathrm{~min}): \lambda_{\mathrm{ex}}=488 \mathrm{~nm}, \lambda_{\mathrm{em}}=500-550 \mathrm{~nm}$. Mito-tracker Red $(0.1 \mu \mathrm{M}, 15 \mathrm{~min}): \lambda_{\mathrm{ex}}=561 \mathrm{~nm}, \lambda_{\mathrm{em}}=570-620 \mathrm{~nm}$. Scale bar: $20 \mu \mathrm{m}$. 


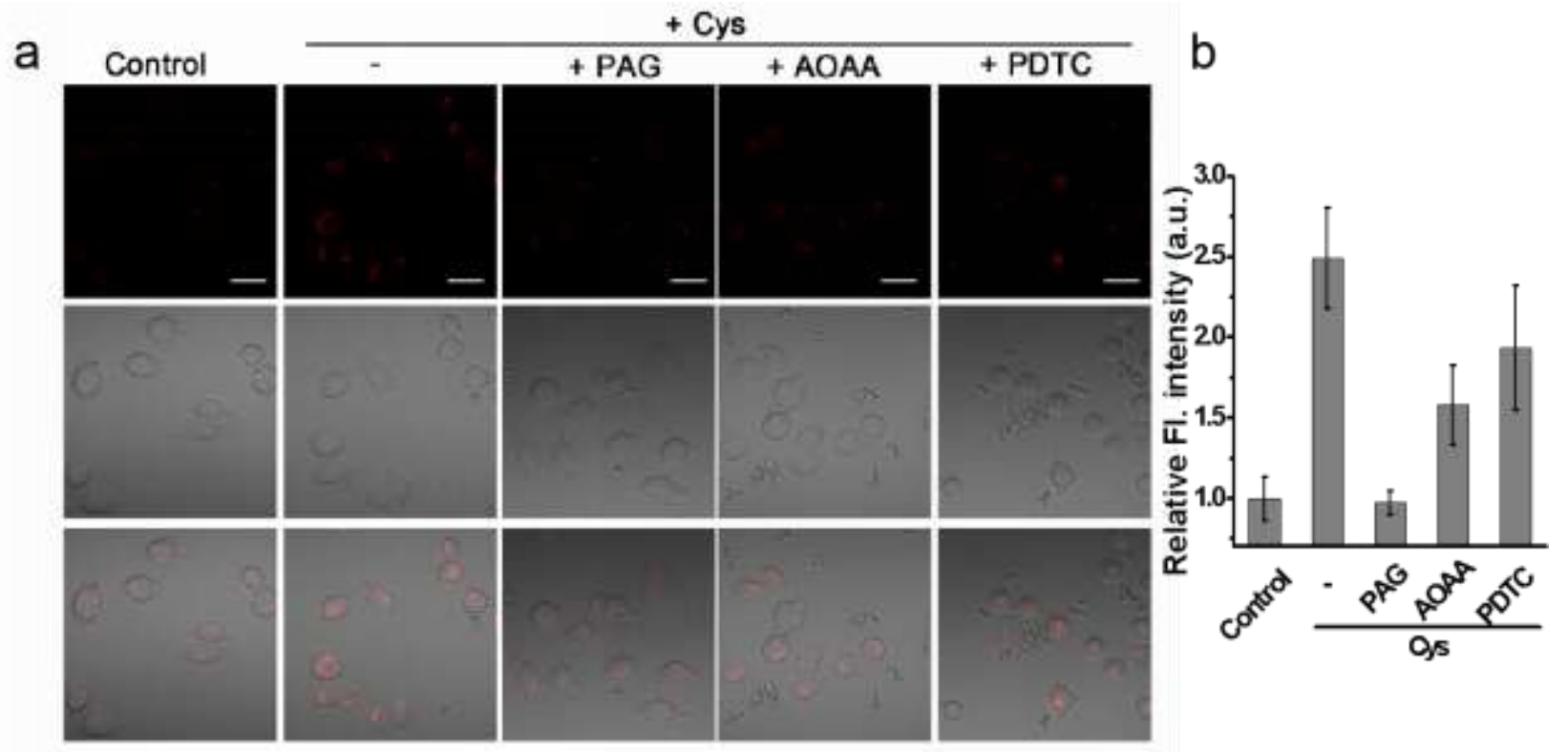

Figure. S22. (a) Confocal microscopy images of endogenous $\mathrm{H}_{2} \mathrm{~S}$ generated from Cys in live HL-7702 cells using nanoprobe MSN@CSN@PEG (100 $\mu \mathrm{g} / \mathrm{mL})$. First column: cells incubated with nanoprobe for 2 h prior imaging; Second column: incubation with $1 \mathrm{mM}$ Cys for $1.5 \mathrm{~h}$ before treatment with the nanoprobe; Third to fifth columns: pretreatment with PAG $(1 \mathrm{mM})$, AOAA $(300 \mu \mathrm{M})$, or PDTC $(200 \mu \mathrm{M})$ for $1.5 \mathrm{~h}$, respectively, before treatment with $1 \mathrm{mM}$ Cys for $1.5 \mathrm{~h}$ and then incubation nanoprobe for $2 \mathrm{~h}$. $\lambda_{\mathrm{ex}}=640 \mathrm{~nm}, \lambda_{\mathrm{em}}=660-738 \mathrm{~nm}$.. Scale bar: $20 \mu \mathrm{m}$. (b) Relative fluorescence intensity of red channel in cells were acquired from (a). Data represent mean standard error ( $n=3$ independent experiments).

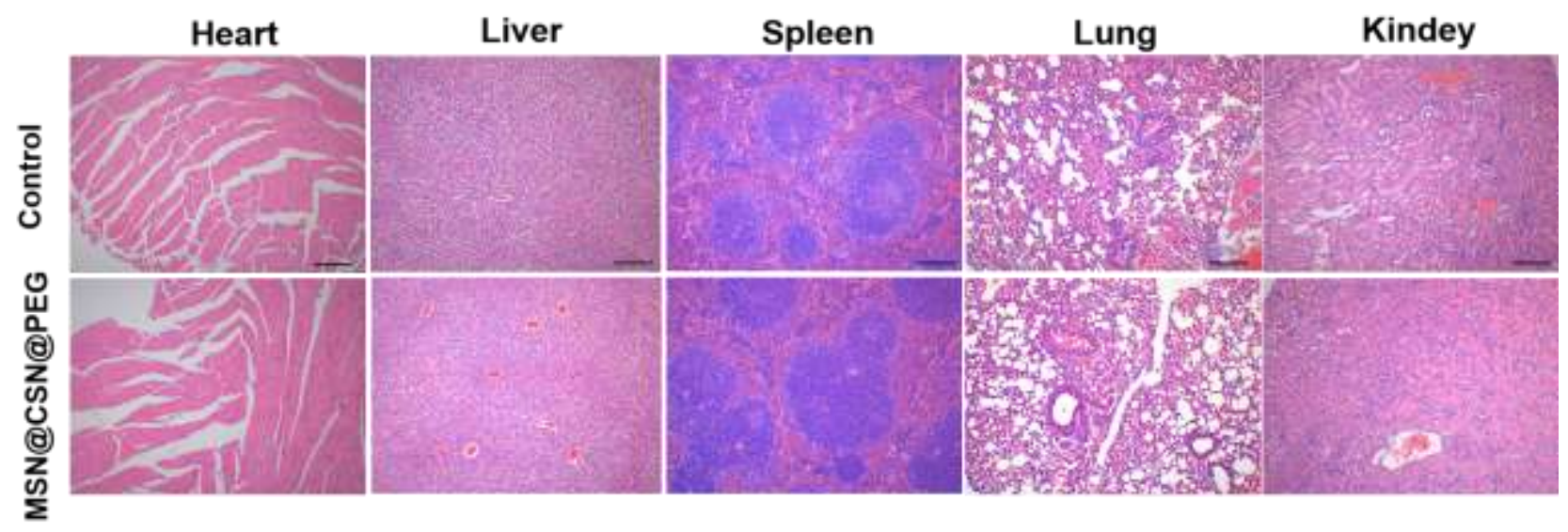

Figure. S23. H\&E staining in heart, liver, spleen, lung and kidneys of mice after intravenous injection with $100 \mu \mathrm{L}$ nanoprobe MSN@CSN@PEG (1 mg/mL) and PBS (as control group) for 24 h. Scale bar: $200 \mu \mathrm{m}$. 


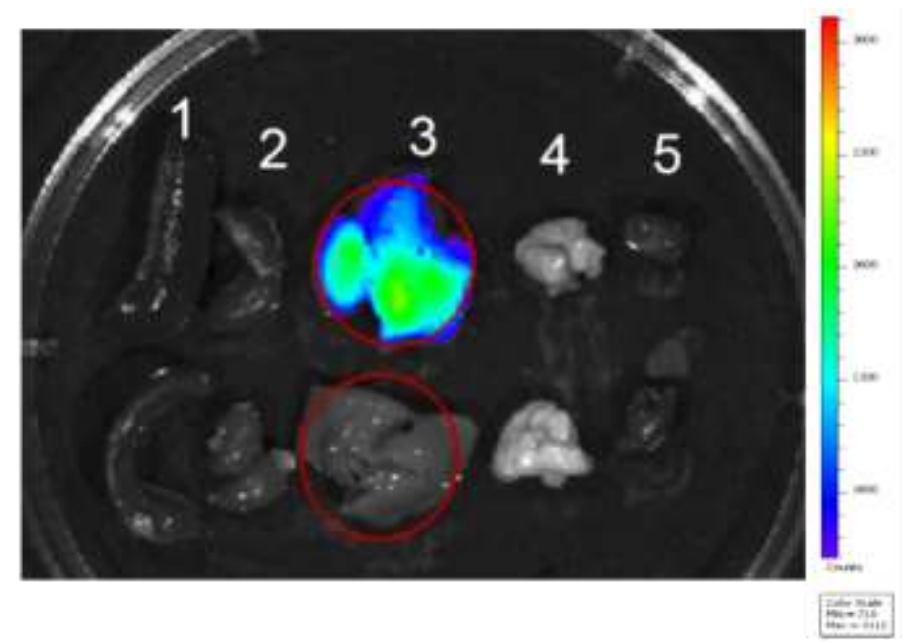

Figure. S24. Fluorescence imaging of MSN@CSOH-CI@PEG $(10 \mathrm{mg} / \mathrm{mL}, 100 \mu \mathrm{L})$ in the main organs of mice. First row: intravenous injection of MSN@CSOH-CI@PEG, second row: intravenous injection of PBS control group. 1: Spleen; 2: Kidney; 3: Liver; 4: Lung; 5: Heart. $\lambda_{\mathrm{ex}}=675 \mathrm{~nm}$, fluorescence collection range was from 710-780 nm.
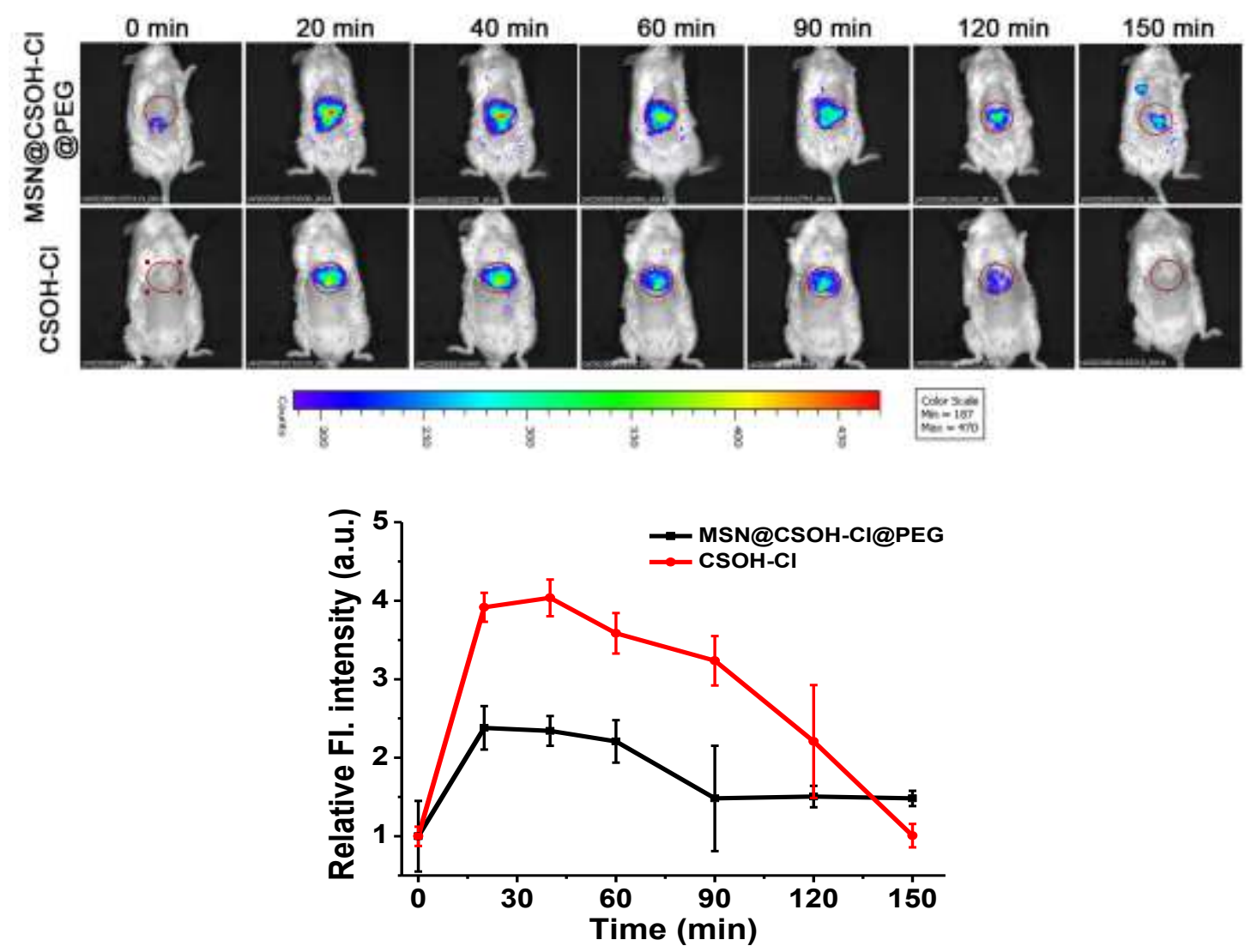

Figure. S25. Real-time NIR fluorescence imaging of MSN@CSOH-CI@PEG (10 mg/mL, $100 \mu \mathrm{L})$ and small molecule dye CSOH-Cl $(100 \mu \mathrm{M}, 100 \mu \mathrm{L})$ in liver of mice. $\lambda_{\mathrm{ex}}=675 \mathrm{~nm}$, fluorescence collection range was from $710-780 \mathrm{~nm}$. 

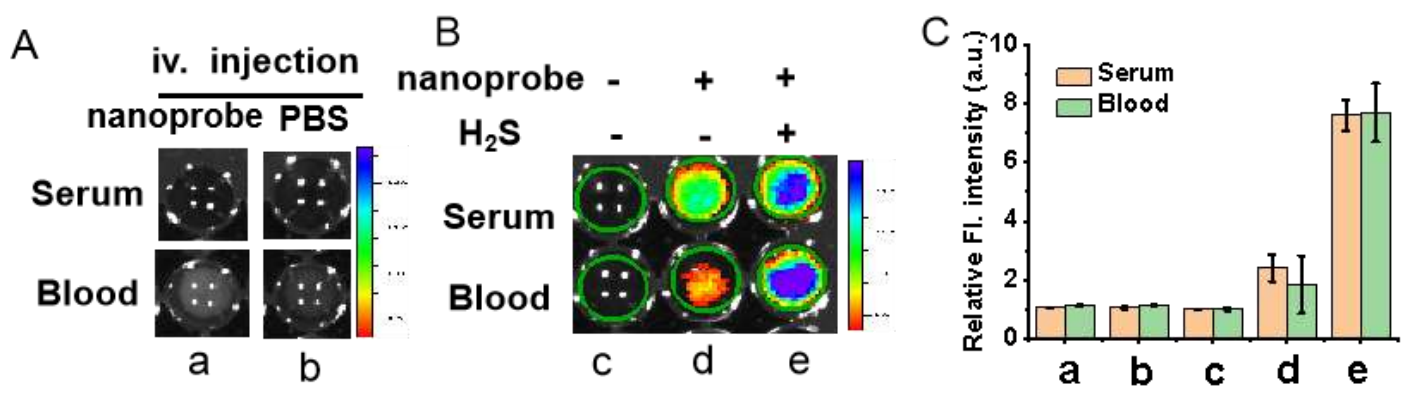

Figure. 26. Fluorescence imaging of mice blood and serum samples in 96-well plates. (A) The nanoprobe MSN@CSN@PEG (1 mg/mL) (a) and PBS (b) were injected into the mice by tail intravenous injection for $0.5 \mathrm{~h}$, and then their blood and serum were taken for fluorescence imaging. (B) The diluted serum and blood samples were untreated (c) or incubated with MSN@CSN@PEG (100 $\mu \mathrm{g} / \mathrm{mL})$ (d) or MSN@CSN@PEG (100 $\mu \mathrm{g} / \mathrm{mL})+100 \mu \mathrm{M} \mathrm{H}_{2} \mathrm{~S}$ (e) in PBS solution for $2 \mathrm{~h}$. (C) Normalized fluorescence intensity of every ostiole for different administration in (A) and (B). The results are the mean standard deviation of three separate measurements. $\lambda_{\mathrm{ex}}=675 \mathrm{~nm}$, fluorescence collection range 710-780 nm. Data represent mean standard error $(n=3)$. 


\section{NMR and HRMS spectra of synthesis compounds}

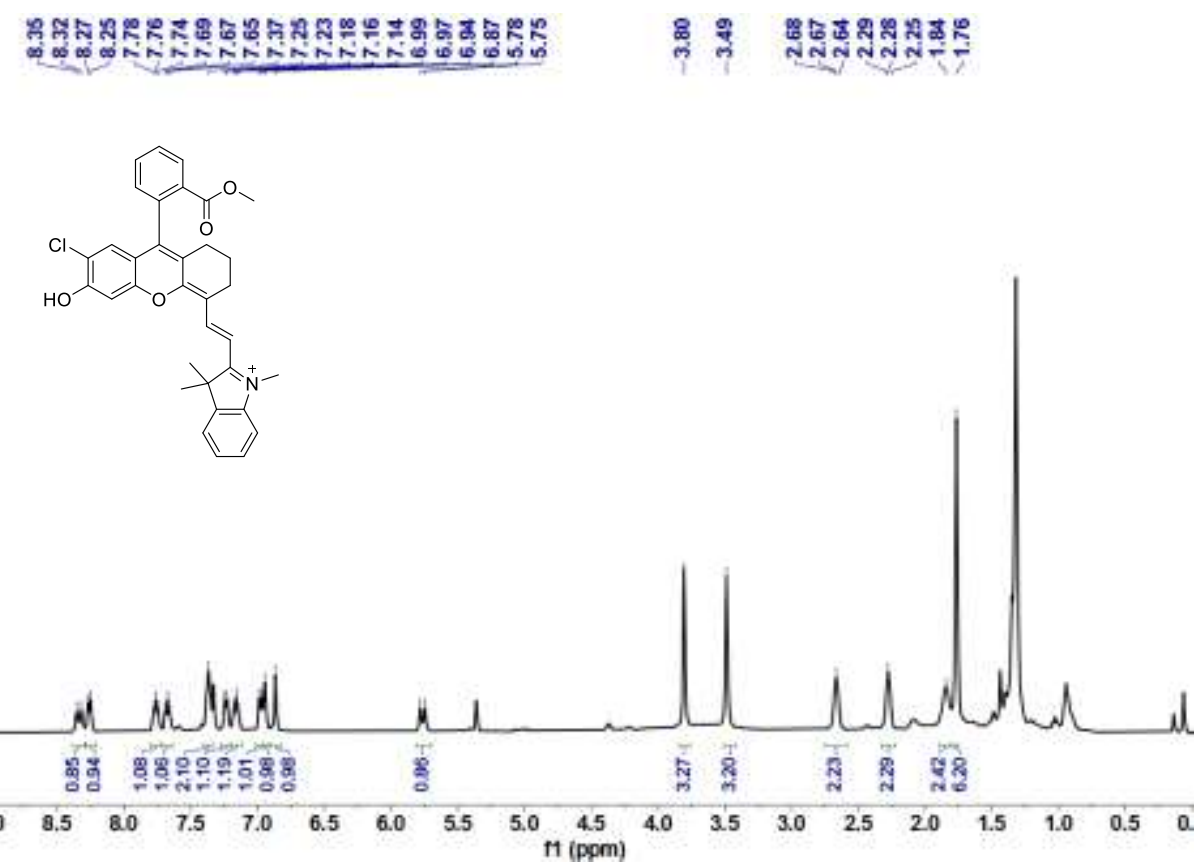

${ }^{1} \mathrm{H}$ NMR (400 MHz, $\mathrm{CDCl}_{3}$ ) spectrum of compound $\mathbf{C S O H}-\mathbf{C l}$

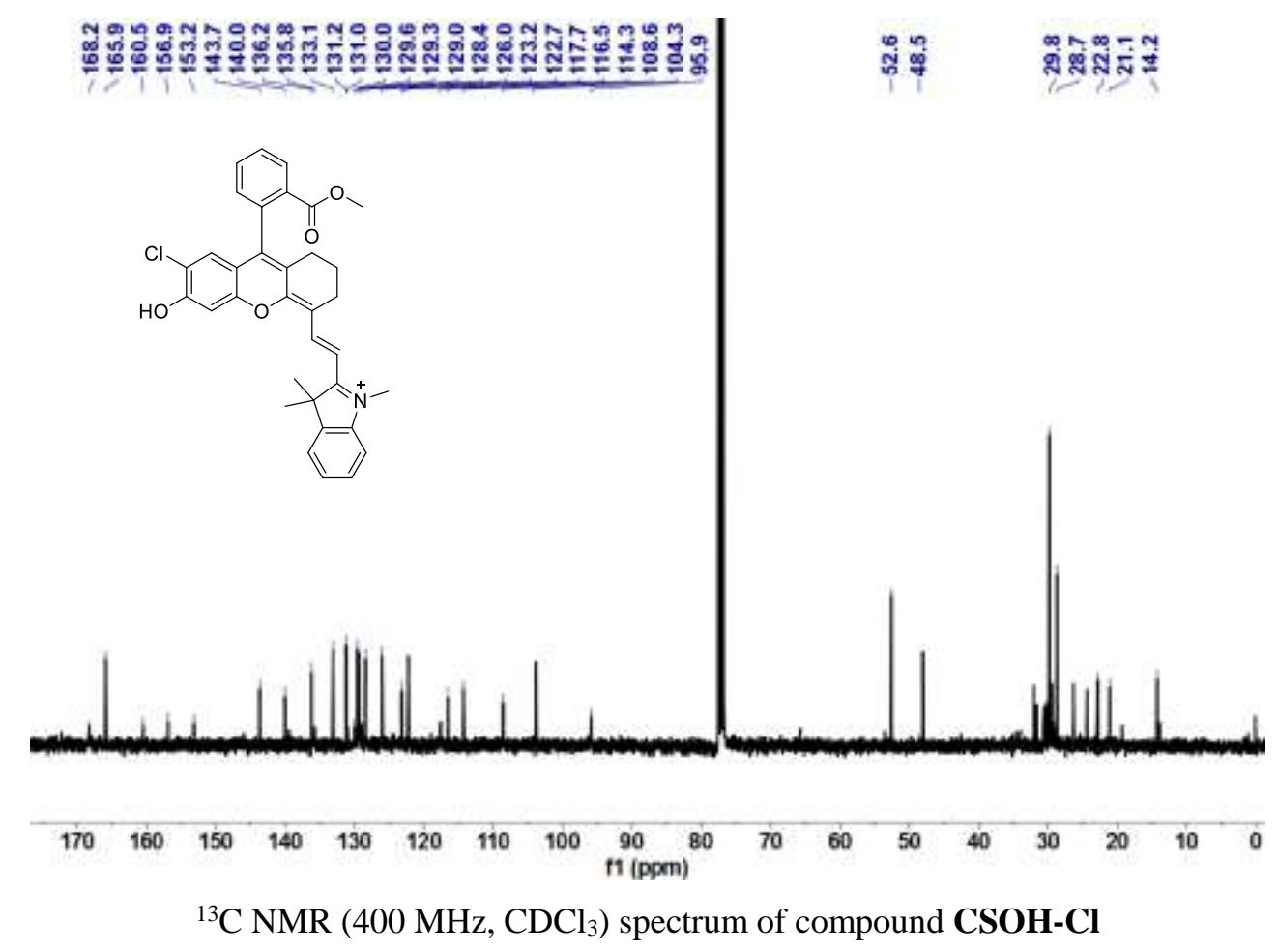




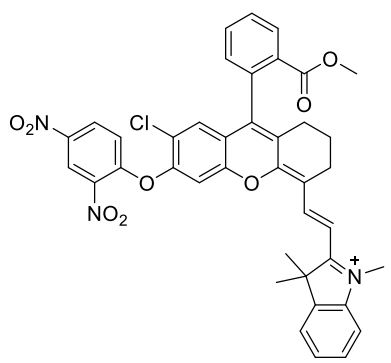

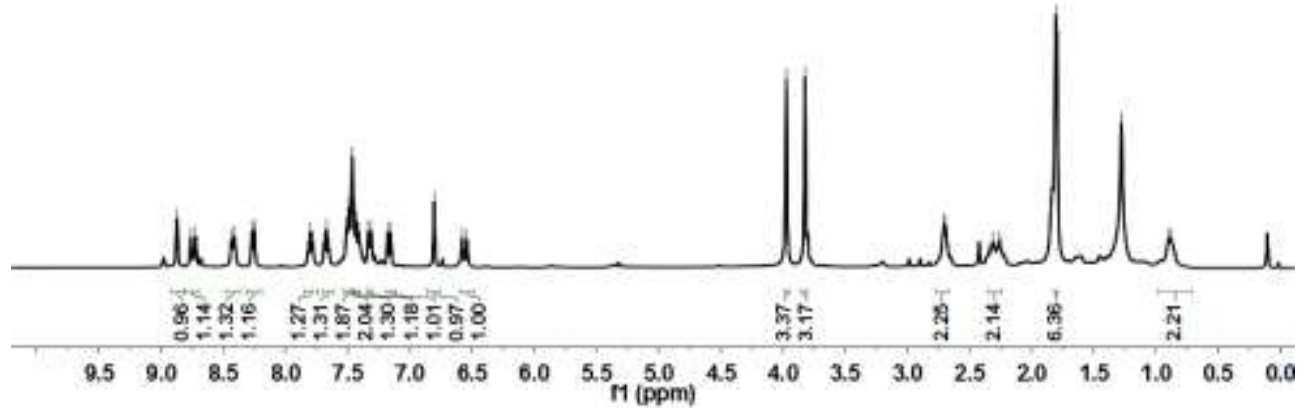

${ }^{1} \mathrm{H}$ NMR (400 MHz, $\mathrm{CDCl}_{3}$ ) spectrum of compound 1-CSN

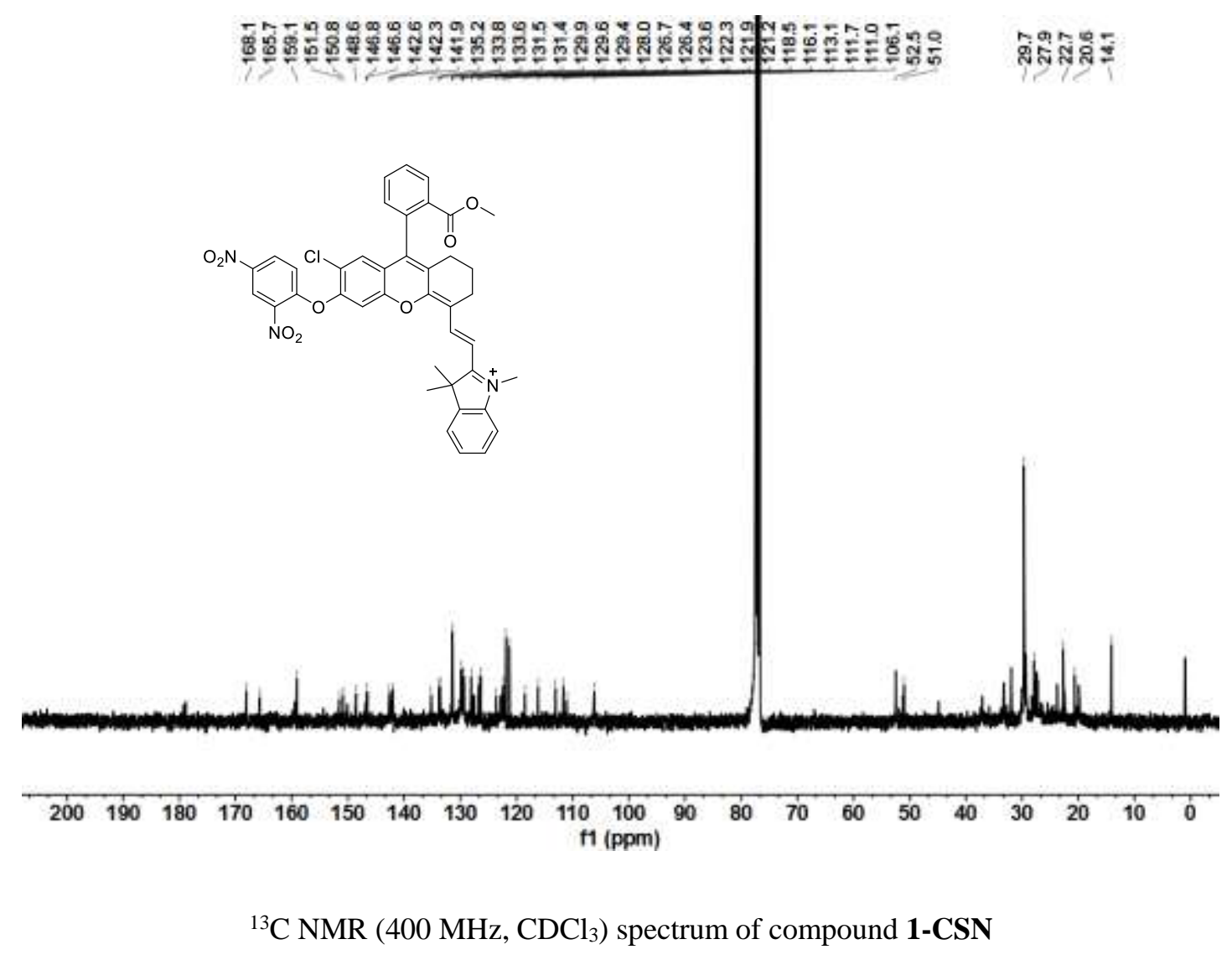



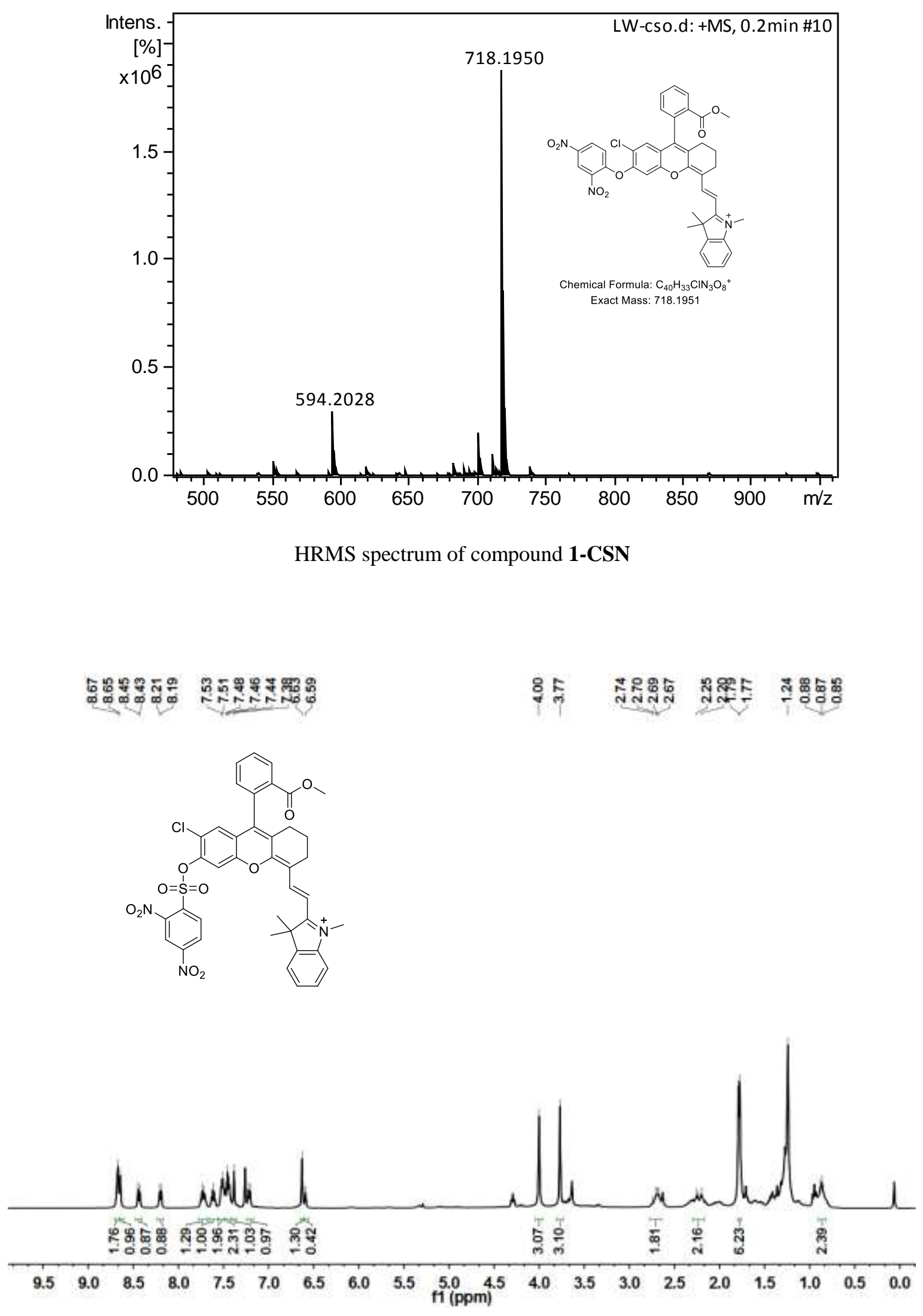

${ }^{1} \mathrm{H}$ NMR (400 MHz, $\mathrm{CDCl}_{3}$ ) spectrum of compound $\mathbf{2}-\mathbf{S O}_{\mathbf{3}} \mathbf{N}$ 

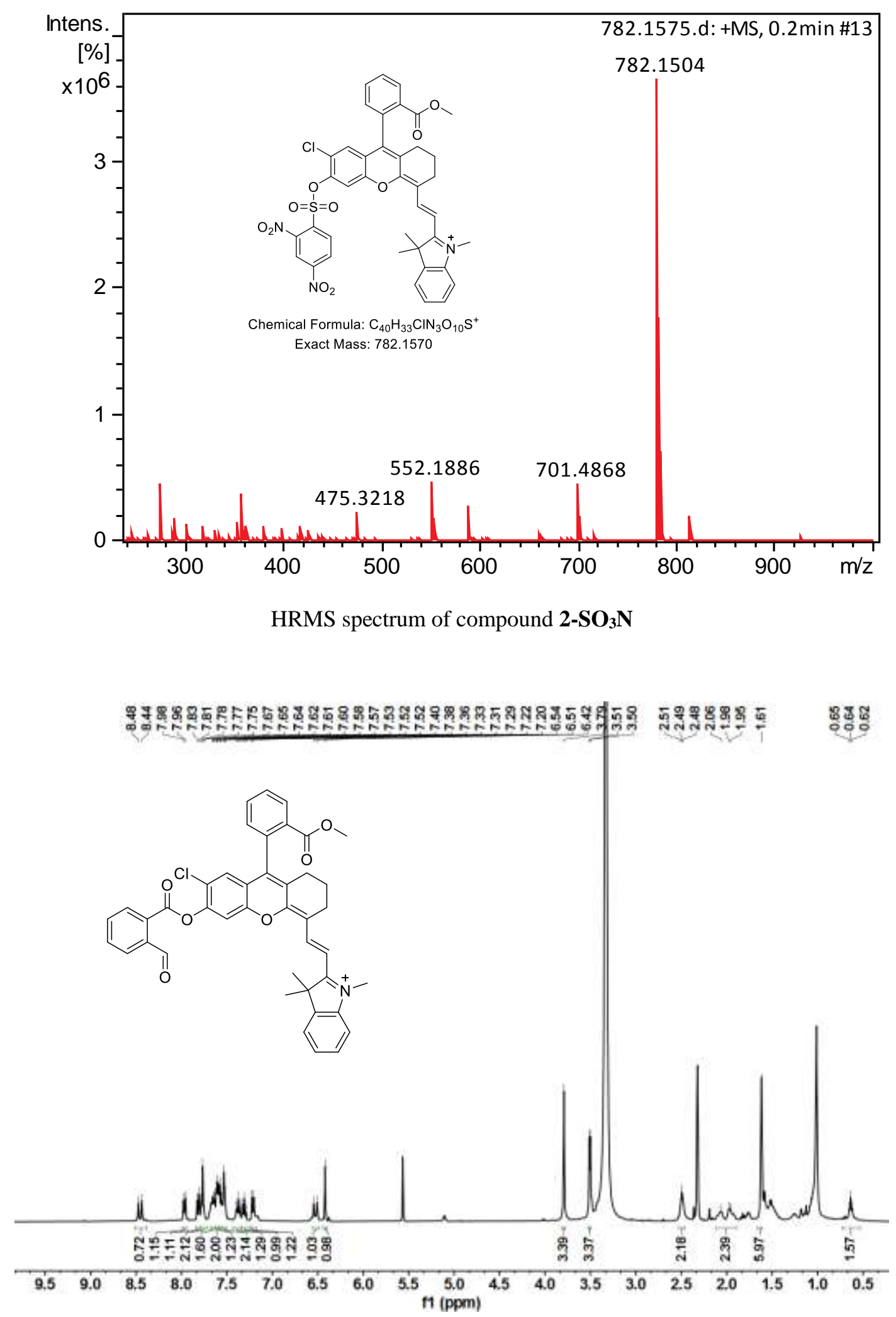

${ }^{1} \mathrm{H}$ NMR (400 MHz, DMSO-d $d_{6}$ ) spectrum of compound 3-CHO 


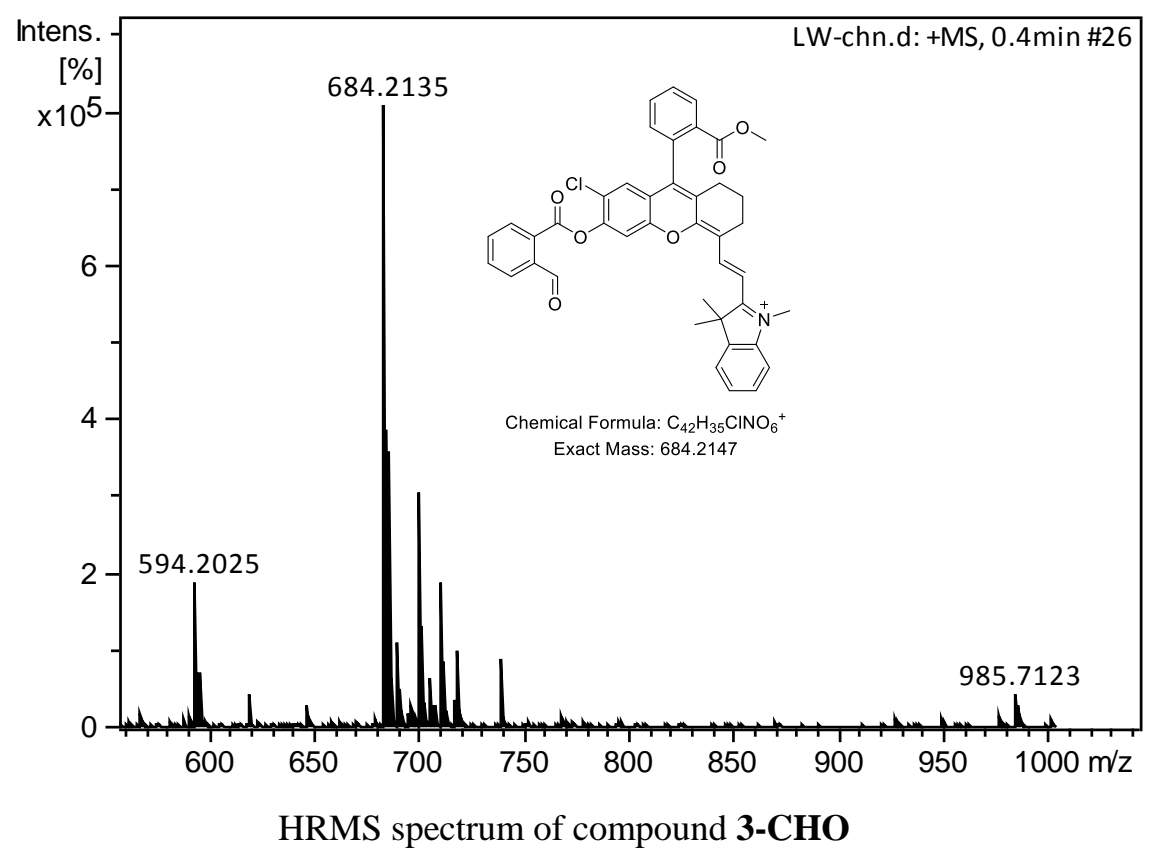

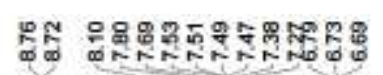

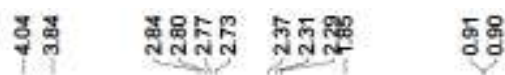<smiles></smiles>

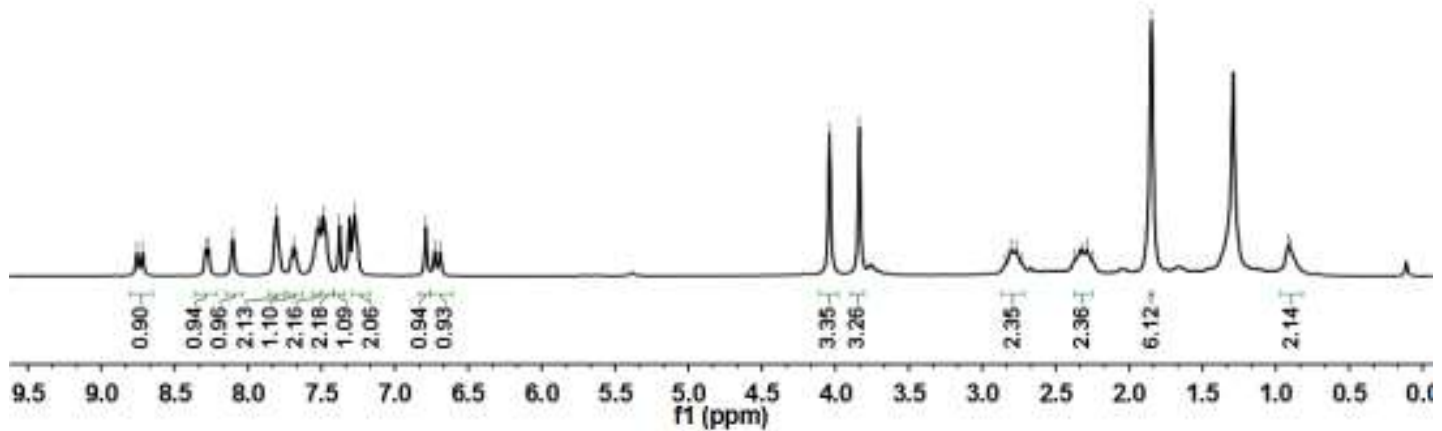

${ }^{1} \mathrm{H}$ NMR (400 MHz, $\mathrm{CDCl}_{3}$ ) spectrum of compound 4-Thia 


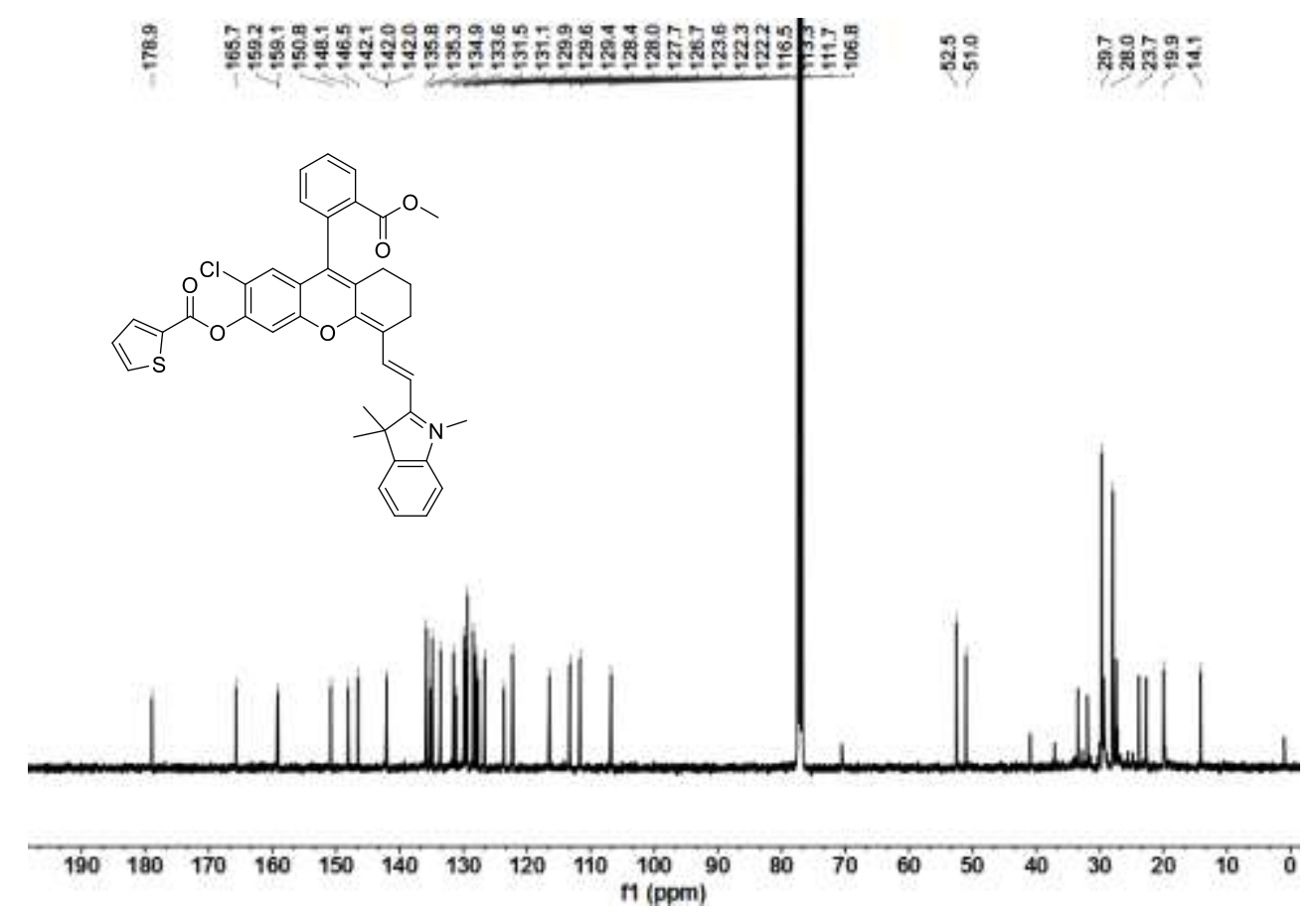

${ }^{13} \mathrm{C}$ NMR (400 MHz, $\mathrm{CDCl}_{3}$ ) spectrum of compound 4-Thia

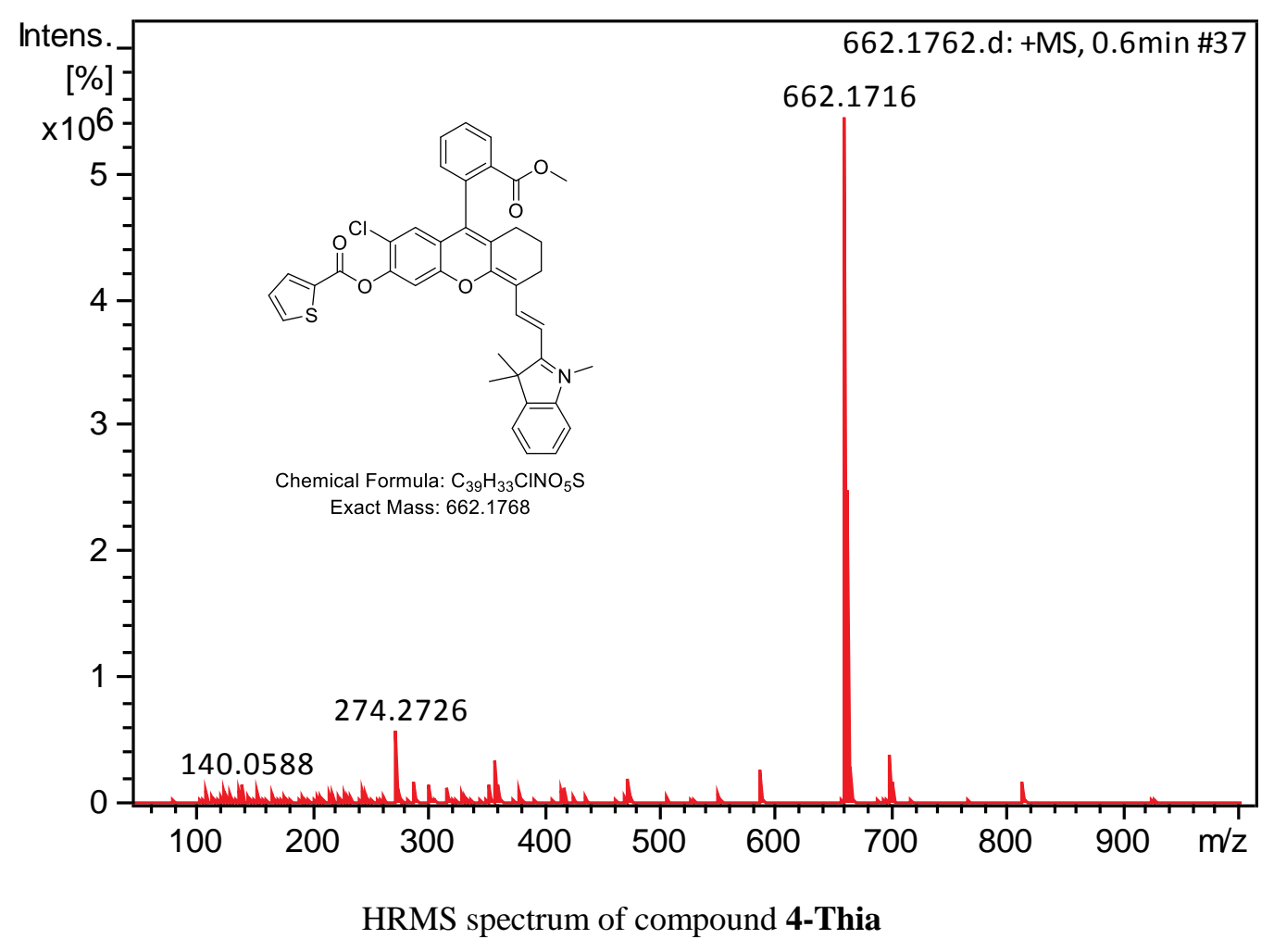


<smiles></smiles>

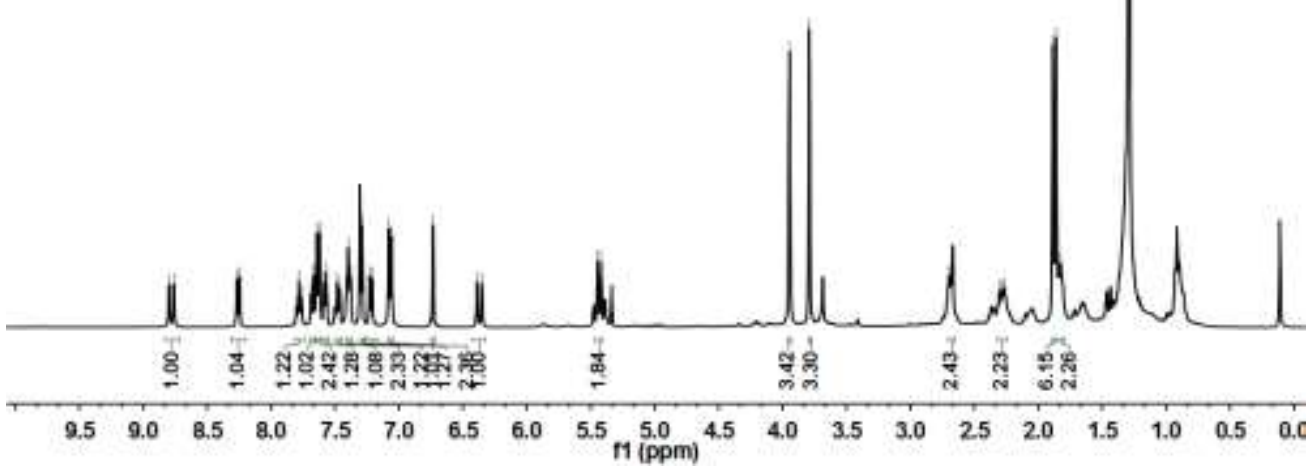

${ }^{1} \mathrm{H}$ NMR (400 MHz, $\mathrm{CDCl}_{3}$ ) spectrum of compound $\mathbf{5}-\mathbf{B N}_{3}$
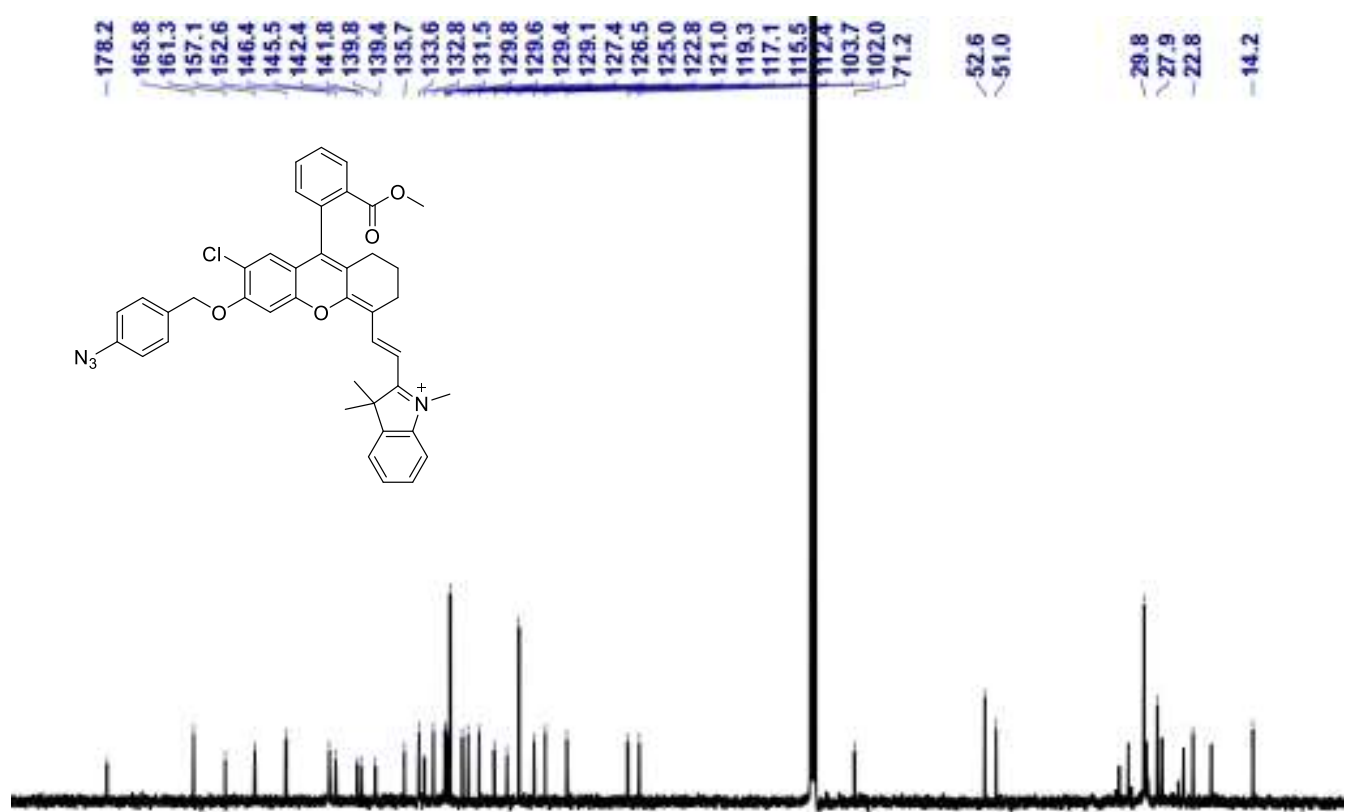

$\begin{array}{lllllllllllllllllll}190 & 180 & 170 & 160 & 150 & 140 & 130 & 120 & 110 & \begin{array}{c}100 \\ f 1(\mathrm{ppm})\end{array} & 90 & 80 & 70 & 60 & 50 & 40 & 30 & 20 & 10\end{array}$

${ }^{13} \mathrm{C}$ NMR (400 MHz, $\mathrm{CDCl}_{3}$ ) spectrum of compound $\mathbf{5}-\mathbf{B N}_{\mathbf{3}}$ 


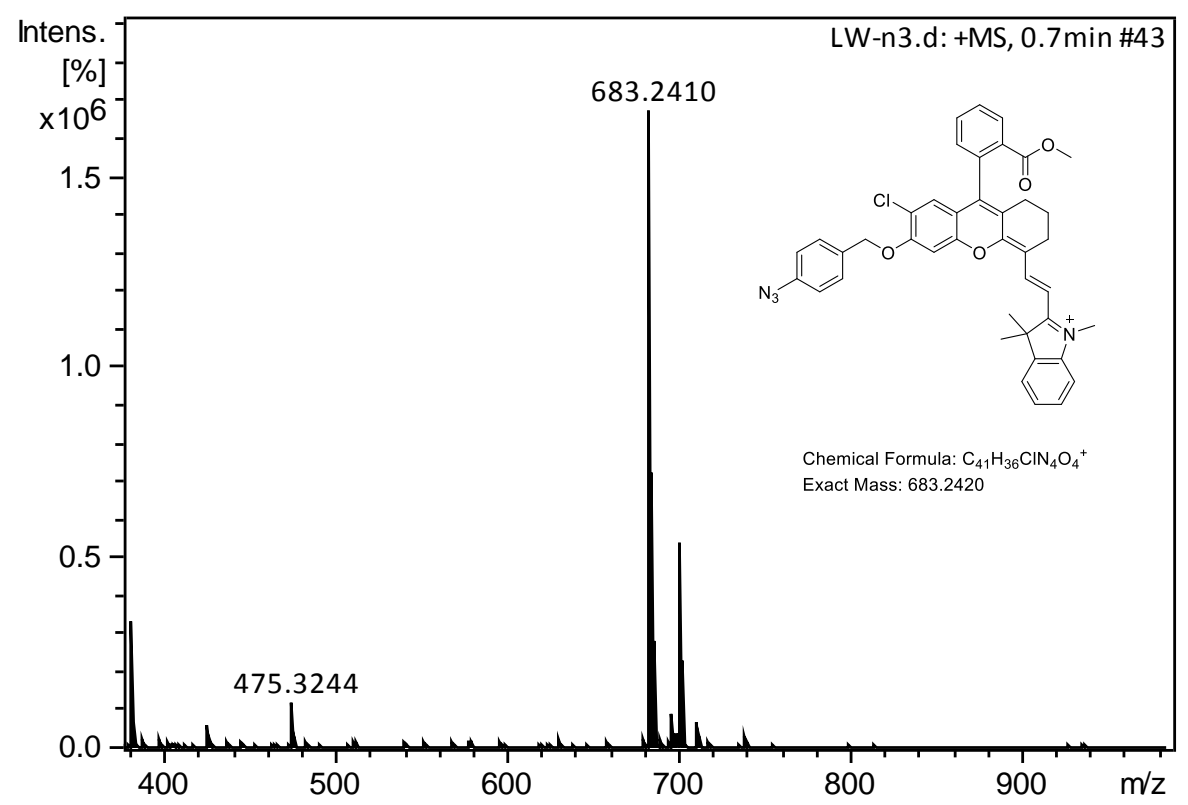

HRMS spectrum of compound $\mathbf{5}-\mathbf{B N}_{3}$

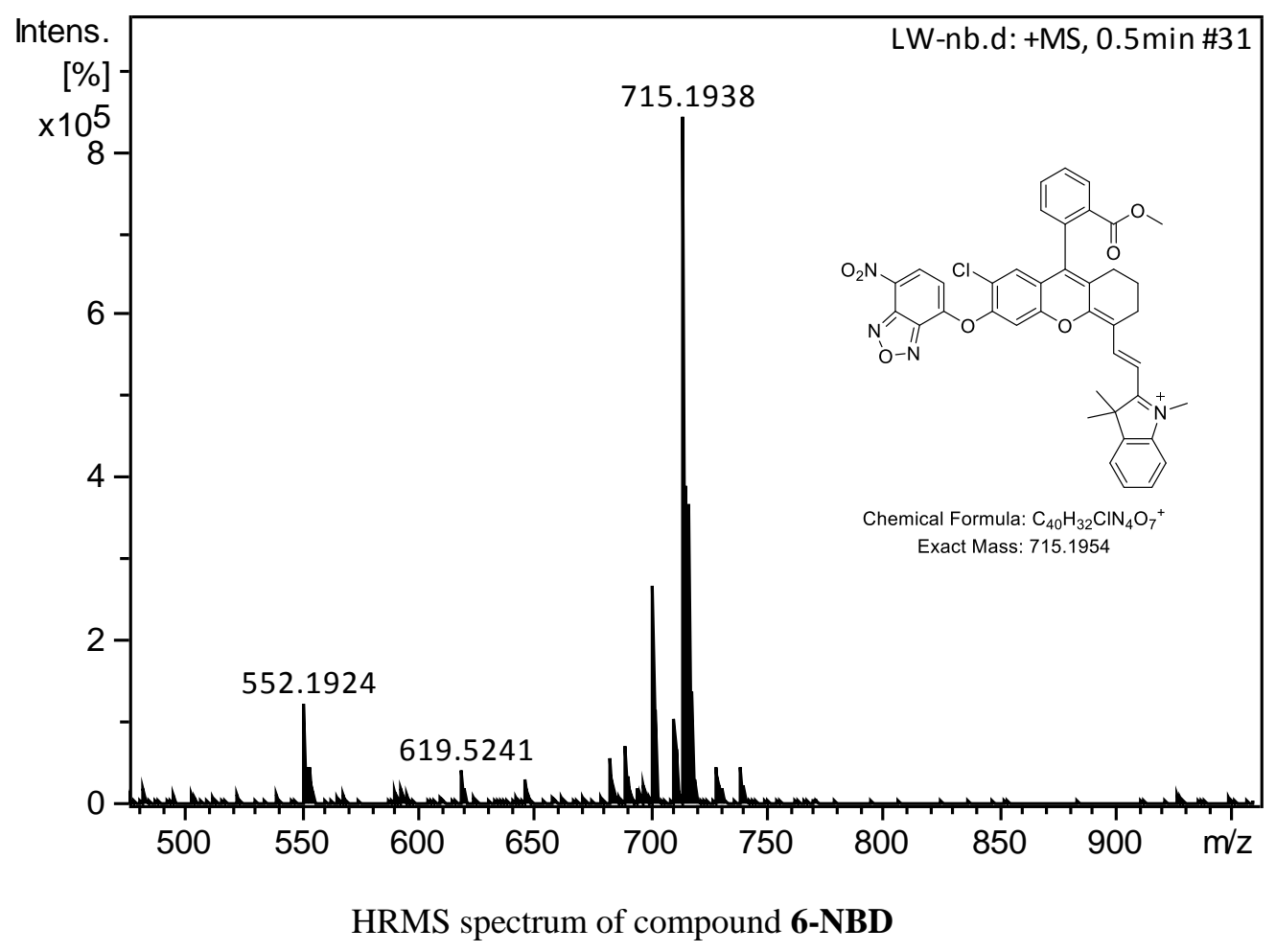




\section{Supplemental References}

(1) Trewyn, B. G., Slowing, I. I., Giri, S., Chen, H. T., \& Lin, S. Y. Synthesis and Functionalization of a Mesoporous Silica Nanoparticle Based on the Sol-Gel Process and Applications in Controlled Release, Acc. Chem. Res. 2007, 40, 846853.

(2) Xiong, X., Song, F., Chen, G., Sun, W., Wang, J., Gao, P., Zhang, Y., Qiao, B., Li, W., Sun, S., Fan, J., Peng, X. Construction of long-wavelength fluorescein analogues and their application as fluorescent probes, Chemistry 2013, 19, 6538-6545. 